\title{
The Roles of the Let-7 Family of MicroRNAs in the Regulation of Cancer Stemness
}

\author{
Yuxi Ma ${ }^{1,2}{ }^{-}$, Na Shen ${ }^{1,3}$, Max S. Wicha ${ }^{1, *}$ and Ming Luo ${ }^{1, *}$ \\ 1 Department of Internal Medicine, Division of Hematology and Oncology, University of Michigan, \\ Ann Arbor, MI 48109, USA; yuxima@hust.edu.cn (Y.M.); nashen@hust.edu.cn (N.S.) \\ 2 Cancer Center, Union Hospital, Tongji Medical College, Huazhong University of Science and Technology, \\ Wuhan 430022, China \\ 3 Department of Breast and Thyroid Surgery, Union Hospital, Tongji Medical College, Huazhong University of \\ Science and Technology, Wuhan 430022, China \\ * Correspondence: mwicha@med.umich.edu (M.S.W.); mingluo@med.umich.edu (M.L.)
}

Citation: Ma, Y.; Shen, N.; Wicha, M.S.; Luo, M. The Roles of the Let-7 Family of MicroRNAs in the Regulation of Cancer Stemness. Cells 2021, 10, 2415. https://doi.org/ 10.3390/cells10092415

Academic Editor: Giorgio Malpeli

Received: 10 August 2021

Accepted: 8 September 2021

Published: 14 September 2021

Publisher's Note: MDPI stays neutral with regard to jurisdictional claims in published maps and institutional affiliations.

Copyright: (c) 2021 by the authors. Licensee MDPI, Basel, Switzerland. This article is an open access article distributed under the terms and conditions of the Creative Commons Attribution (CC BY) license (https:// creativecommons.org/licenses/by/ $4.0 /)$.

\begin{abstract}
Cancer has long been viewed as a disease of normal development gone awry. Cancer stemlike cells (CSCs), also termed as tumor-initiating cells (TICs), are increasingly recognized as a critical tumor cell population that drives not only tumorigenesis but also cancer progression, treatment resistance and metastatic relapse. The let-7 family of microRNAs (miRNAs), first identified in C. elegans but functionally conserved from worms to human, constitutes an important class of regulators for diverse cellular functions ranging from cell proliferation, differentiation and pluripotency to cancer development and progression. Here, we review the current state of knowledge regarding the roles of let-7 miRNAs in regulating cancer stemness. We outline several key RNA-binding proteins, long non-coding RNAs (lncRNAs) and circular RNAs (circRNAs) involved in the regulation of let-7 biogenesis, maturation and function. We then highlight key gene targets and signaling pathways that are regulated or mutually regulated by the let-7 family of miRNAs to modulate CSC characteristics in various types of cancer. We also summarize the existing evidence indicating distinct metabolic pathways regulated by the let-7 miRNAs to impact CSC self-renewal, differentiation and treatment resistance. Lastly, we review current preclinical studies and discuss the clinical implications for developing let-7-based replacement strategies as potential cancer therapeutics that can be delivered through different platforms to target CSCs and reduce/overcome treatment resistance when applied alone or in combination with current chemo/radiation or molecularly targeted therapies. By specifically targeting CSCs, these strategies have the potential to significantly improve the efficacy of cancer therapies.
\end{abstract}

Keywords: cancer stem cells (CSCs); tumor suppressor microRNAs; long non-coding RNAs (lncRNAs); circular RNAs (circRNAs); lin28; glucose metabolism

\section{Introduction}

MicroRNAs (miRNAs) are a small class of non-coding RNAs identified as evolutionary conserved, single-strand RNAs with the size of 18-25 nucleotides. Functionally, miRNAs repress target gene expression by binding to the $3^{\prime}$-untranslated regions ( $3^{\prime}$ UTRs) of target messenger RNAs (mRNAs) to promote degradation and prevent their translation into protein products. Since the initial discovery of C. elegans miRNA gene (lin-14) in the early 1990s [1], over 2000 miRNAs have been identified, which regulate diverse cellular processes, including proliferation, differentiation, survival, stem cell maintenance and tumorigenesis $[2,3]$. It has been well established that miRNAs play crucial roles in tumor development and progression by regulating key cancer regulatory genes, including oncogenes and/or tumor suppressor genes [2].

Let-7 (lethal-7) was initially identified as a heterochronic gene in C. elegans (the second miRNA gene identified after lin-14), where its expression determines adult cell fate in the 
worm [4].The let-7 family of miRNAs, which is comprised of multiple paralog genes located in different chromosomes, has been defined as one of the largest and most conserved family of miRNAs across different species, ranging from worms to humans [5-7]. In humans, there are 10 mature let-7 miRNAs, including let-7a, let-7b, let-7c, let-7d, let-7e, let-7f, let-7g, let-7i, miR-98 and miR-202, which are derived from 13 precursor genes [8].

During mammalian embryonic development, let-7 expression is silent in embryonic stem cells (ESCs) but reactivated at later development stages [5]. This role of let-7 in ESC differentiation is further validated by the findings that exogenous expression of let-7 in miRNA-deficient ESCs rescues their defective differentiation [9]. In cancer cells, the let-7 family of miRNAs generally function as tumor suppressor miRNAs to inhibit tumor growth and metastasis $[8,10,11]$. Let-7 miRNAs are also involved in suppressing CSC characteristics, including sphere/colony formation, tumor growth, differentiation and regenerative potential $[8,10,11]$.

Cancer stem cells (CSCs), or tumor-initiating cells (TICs), represent a small subset of cells in the tumor that maintain or acquire the capacity to indefinitely self-renew as well as to differentiate into various tumor cell progenies constituting the bulk of a tumor mass $[12,13]$. As CSCs are endowed with the intrinsic capacity for therapeutic resistance, they contribute not only to tumorigenesis but also to disease progression and metastatic relapse. As a result of these properties, CSCs play a major role in the resistance of tumors to the conventional chemotherapy and radiation therapy [13].

miRNAs, especially the let-7 family of miRNAs and their regulatory proteins, are frequently deregulated in a wide variety of cancer types and influence CSC maintenance, metabolism, tumorigenesis and metastasis. This review summarizes the current state of knowledge on the roles of let-7 miRNAs and their regulatory proteins in regulating CSCs during tumor development and cancer progression, the signaling pathways and network through which let-7 miRNAs are involved in the regulation of CSCs. We also emphasize existing strategies that have been documented in the literature to harness this family of miRNAs for therapeutic benefit in preclinical models.

\section{Let-7 as Key Tumor Suppressor miRNAs and Negative Regulators of CSCs}

The CSC model posits that cancer arises from a rare population of tumor-initiating cells (TICs) or CSCs that possess dysregulated self-renewal capacity. Yu et al. presented the first evidence that let-7 miRNAs are markedly reduced in TICs but increased in differentiated tumor cells in breast cancer [14]. This increased let-7 expression in differentiated tumor cells (or non-TICs) inhibits the expression of H-Ras and HMGA2, known let-7 target genes that promote tumor self-renewal and proliferative capacity. In contrast, antagonizing let-7 by antisense oligonucleotides enhances self-renewal capacity of non-TICs, indicating a critical role of let-7 miRNAs in suppressing tumorigenicity by downregulating CSC properties [14].

In addition to a role in regulating breast CSCs (BCSCs), let-7 miRNAs are also implicated in CSC regulation in other tissue malignancies. For instance, let-7a is downregulated in stem-like cells in head and neck cancers as evidenced by their expression of aldehyde dehydrogenase (ALDH). Furthermore, increased let-7a expression represses chemoresistance and tumourigenicity through the ablation of CSC-like properties [15].

In human pancreatic cancer cells, CD44+/CD133+/EpCAM+ CSC-like cells exhibited lower levels of let-7 expression [16], and this suppressed let-7 expression promoted the expression of pluripotency transcription factor, such as NANOG, SOX2, SOX9, OCT4, KLF4 and c-myc, to maintain CSCs. In gastric cancer, let-7b was shown to directly suppress c-myc expression to promote gastric stem cell differentiation and drug sensitivity [17].

In urothelial carcinoma of the bladder or UCB, the activation of pro-inflammatory COX2/PGE2 signaling induces promoter methylation of let-7, resulting in its downregulation and subsequent upregulation of SOX2, which promotes the maintenance of urothelial CSCs [18]. In therapy-induced neuroendocrine prostate cancer (t-NEPC), upregulated Lin28B suppresses let-7 miRNA expression, which, in turn, promotes the de-repression of HMGA2 and HMGA2-mediated SOX2 expression, leading to increased CD44+ and CD133+ CSC-like cell populations [19]. 
Epithelial-mesenchymal transition or EMT, a cellular process facilitating tumor cell invasion, migration and dissemination has been shown to associate with the acquisition of mesenchymal CSC-like properties [20]. Increased Lin28A expression remarkably increases E-cadherin but reduces Vimentin expression and, subsequently, increases the epithelial CSC marker ALDH activity and colony formation via the downregulation of let-7a in breast cancer [21].

The suppression of let-7d expression activates key EMT transcriptional factors, including Twist and Snail, and promotes chemo-resistant abilities of oral squamous cell carcinoma [22]. In tongue squamous cell carcinoma (TSCC), the long noncoding RNA (lncRNA) H19, by binding to (sponging) let-7a to inhibit its function in repressing let-7 target gene HMGA2, facilitates TSCC cell migration and invasion [23].

In advanced high grade serous ovarian cancer (HGSOC), knockdown of Snail upregulates let-7 expression and reverses the cancer stemness phenotype [24]. Similarly, in HGSOC, low levels of let-7 expression were associated with increased EMT and higher spheroid-forming and tumor growth capacities [25]. The overexpression of mir-98, a member of let-7 family of miRNAs, reverses EMT through directed targeting of HMGA2 and transcriptional repression of the EMT-related gene POSTN [26].

\section{Regulatory Mechanisms of Let-7 Expression and Function}

\subsection{Let-7 Biogenesis}

The biogenesis of let-7 is similar to that of other miRNAs. Canonical let-7 miRNAs are first transcribed from the corresponding miRNA transcription units by RNA polymerase II to produce primary miRNAs (pri-miRNAs), which are subsequently processed by a complex containing an RNase III-like enzyme Drosha and its co-factor DGCR8, a doublestranded RNA-binding protein (RBP), into a 60-70nt-long precursor miRNAs (pre-miRNAs) in the nucleus [27-30].

The pre-miRNAs are then transported to the cytoplasm by exportin 5 and further cleaved by Dicer, a cytoplasmic RNase III, to generate 18-25 bp long miRNA duplex [31-35]. One of the miRNA strands (called guide strand) in the duplex recruits Argonaute proteins (AGO1-4) to form RNA-induced silencing complex (RISC), while the other strand (passenger strand) is degraded. The RISC mediates post-transcriptional repression of miRNA (i.e., let-7) target genes, where the guide strand of miRNAs acts as a tether to the 3'UTR of specific mRNAs to cause their degradation and translational repression [36].

\subsection{Post-Transcriptional Regulation of Let-7 by RNA-Binding/Processing Proteins}

Let-7 constitutes a 13-member tumor suppressor miRNA family downregulated in a large fraction of tumor types [6,7]. Let-7 suppresses the translation of a number of oncogenes, including Myc, K-Ras and HMGA2 [37-39]. The biogenesis of miRNAs, including let-7, is regulated at different stages in the nucleus and cytoplasm by miRNA processing proteins, such as Drosha and Dicer, respectively, and shRNA-mediated downregulation of Drosha or Dicer1-enhanced tumor development in a K-Ras-induced mouse model of lung cancer, suggesting that the abrogation of global miRNA processing promotes tumorigenesis [40].

Subsequently, by examining the consequence of heterozygous vs. homozygous deletion of Dicer1 in mouse models, Kumar et al. demonstrated that the loss of a single allele of Dicer1 enhanced tumorigenesis, while the loss of both alleles had the opposite effect [41]. Indeed, reduced Dicer expression has been shown to predict poor patient survival in a number of cancer types, including chronic lymphocytic leukemia [42], breast [43], lung [44], ovarian [45], colorectal [46] and bladder [47,48] cancer.

In colorectal and breast cancer, low levels or the impairment of Dicer expression promotes epithelial-to-mesenchymal transition (EMT), metastasis formation and the acquisition of cancer stemness [49-51]. In parallel with the role of Dicer functioning as a haplo-insufficient tumor suppressor, recent studies also identified Dicer as a HIF-1 $\alpha$ interacting protein to promote CSC and metastatic activities in multiple types of cancer cell lines and human tumors, where HIF-1 $\alpha$ suppresses Dicer expression by promoting its 
ubiquitination and autophagy-mediated degradation, leading to repressed maturation of known tumor suppressor miRNAs, including let-7 and miRNA-200b [52].

In contrast to Dicer1, DGCR8 and AGO RBPs that mediate let-7 (and other miRNAs) maturation and subsequent silencing of target mRNAs, a subset of RBPs can compete or inhibit miRNA-mediated mRNA silencing by binding sequences at or in close proximity to miRNA recognition elements (MREs) [53]. Of these, Lin28A and Lin28B (collectively referred as Lin28) are best known to suppress let-7 expression and function and to influence stem cell maintenance, metabolism and tumorigenesis [54-58].

Lin28A and Lin28B, two highly related RBPs and proto-oncogenes, inhibit let-7 biogenesis through distinct mechanisms by binding the let-7 precursor (pre-let-7) to interfere with the miRNA-processing-machinery-mediated cleavage [59-61]. Lin28B binds to pre-let-7 and prevents its processing by the miRNA-processing machinery in the nucleus, whereas Lin 28A functions in the cytoplasm to recruit terminal uridylyl transferase (TUT4 or TUT7), which places a short oligo (U) stretch to the $3^{\prime}$-end of pre-let-7, which blocks its processing by Dicer, leading to pre-let-7 degradation [61-63].

Lin28A and Lin28B are aberrantly expressed in a plethora of tissue malignancies, and activation of either Lin28A or Lin28B is responsible for the global post-transcriptional downregulation of let-7 miRNAs in many cancers, which is associated with advanced tumor stages and poor patient outcomes [55]. Through gain-or loss-of-function studies in various cancer cell lines and mouse models, Lin28A/B has been shown to promote tumor growth, invasion and metastasis $[19,57,64,65]$.

In addition to Lin28, other RBPs, such as the insulin-like growth factor 2 mRNA-binding proteins (IMPs), have been characterized to compete with miRNAs for binding to MREs on target mRNAs and protect these transcripts from miRNA-mediated degradation [66]. In glioblastoma, IMP2 prevents let-7 target gene silencing by binding to let-7 MREs, thereby protecting them from degradation, leading to the preservation of glioblastoma stem-like cells [67]. In addition to IMP2, other IMP paralogs, such as IMP1 and IMP3, have also been shown to protect let-7 target genes from silencing [66]. Therefore, the IMPs fulfill a function similar to Lin28 and may cooperate with Lin 28 to induce or maintain stemness in tumor cells.

\subsection{Post-Transcriptional Regulation of Let-7 by LncRNAs and circRNAs}

As depicted in Figure 1, a growing number of studies have shown that long non-coding RNAs (lncRNAs) and circular RNAs (circRNAs) play important roles in tumorigenesis and progression via the regulation of miRNAs, including the let-7 family. The human H19 encodes a lncRNA that acts as a trans regulator of the imprinted gene network controlling growth in mice [68]. H19 harbors both canonical and non-canonical binding sites for the let-7 family of miRNAs, which acts as a molecular sponge for let-7 [69].

Emerging evidence indicated that $\mathrm{H} 19$ plays important roles in regulating tumorigenicity and cancer stemness. For example, high levels of H19 are enriched in breast cancer stem cells (BCSCs), where it functions as a competing endogenous RNA to sponge let-7, leading to increased expression of the core pluripotency factor Lin28, thereby, promoting BCSC maintenance [70]. Through its sponging function, $\mathrm{H} 19$ also facilitates the migration and invasion of tongue squamous cell carcinoma cells by suppressing let-7a, leading to the activation of its target gene HMGA2, which, in turn, promotes EMT [23].

In esophageal cancer cells, elevated H19 expression promotes EMT and metastasis through activation of the STAT3/EZH2/ $\beta$-catenin axis, and, interestingly, H19 was directly targeted by let-7c, suggesting a mutual negative-feedback regulation between $\mathrm{H} 19$ and let-7c [71]. Like H19, the long intergenic non-coding RNA or Linc-ROR, a regulator of cell reprogramming, plays a key role in accelerating the self-renewal capacity of CSCs in pancreas cancer by sponging some members of the let-7 family [72].

In addition to serving as a molecular sponge by binding to let-7, some LncRNAs regulate the let-7 family of miRNAs indirectly by modulating the expression of specific proteins that suppress let-7 maturation or function. In colorectal cancer, lncRNA PVT1-214 is markedly 
increased, which represses let-7 miRNA expression indirectly by inhibiting the degradation of Lin28A, which, in turn, drives the acquisition of stem cell-like properties [73].

In addition to lncRNAs, circular RNAs (circRNAs) are a type of single-stranded RNAs that, unlike linear RNA, form a covalently closed continuous loop. Some circRNAs contain MREs for the let-7 family of miRNAs. For example, circHMCU modulates breast cancer cell proliferation and mesenchymal characteristics by sponging let-7 miRNAs and, subsequently, activates let-7 targeted genes, including HMGA2, c-myc and CCND1 [74].

In non-small cell lung cancer (NSCLC) cells, let-7 is inhibited by circ-CPA4 via its molecular sponge function, and the knockdown of circ-CPA4 inhibited cell growth, mobility and promoted cell death by downregulating the release of exosomal PD-L1, which promotes CSC-like activities and resistance of NSCLC cells to cisplatin [75].

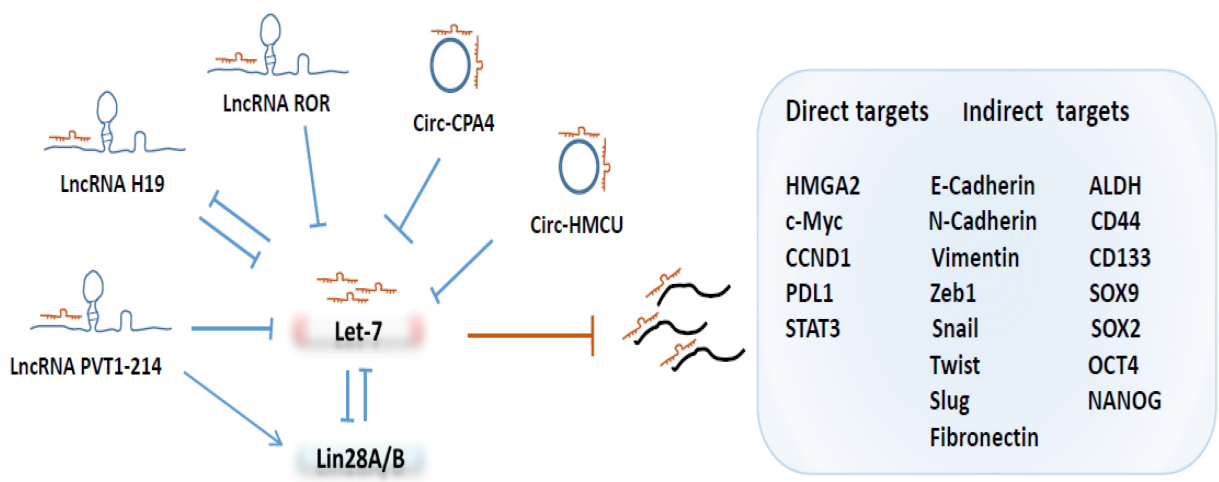

Figure 1. The regulation of let-7 availability and function by LncRNAs and CircRNAs. Several lncRNAs and circRNAs act as molecular sponges to antagonize Let-7 function by limiting its access to mRNAs of target genes, such as HMGA2, c-Myc, CCND1, STAT3 and PDL1, leading to indirect regulation of CSC-related factor expression.

\section{CSC Regulatory Pathways Involving Let-7 miRNAs}

\subsection{Wnt/ $\beta$-Catenin Signaling}

Aberrant Wnt/ $\beta$-catenin signaling promotes CSC self-renewal and proliferative capacity, thus, exerting crucial roles in tumorigenesis and therapy response. Wnt $/ \beta$-catenin signaling is activated in CSCs of multiple types of cancer. As shown in Figure 2, Wnt signaling molecules, including Wnt1, $\beta$-catenin, TCF and CCND1 have been reported to be regulated by the let-7 family of miRNAs. Several studies have indicated that let-7 miRNAs are involved in controlling breast cancer stemness through the mutual regulation of Wnt signaling.

For example, the $\mathrm{Wnt} / \beta$-catenin pathway represses let-7 expression post-transcriptionally by the transactivation of Lin28B, a well-characterized suppressor of let-7 miRNA biogenesis, to augment breast CSC phenotypes [76]. In ER+ breast cancer, elevated let-7c expression decreases the tumorigenicity of CSCs and enhances the antitumor efficacy of tamoxifen through suppression of the ER and the Wnt pathway $[77,78]$. By acting as a specific molecular sponge of let-7c, lncRNA H19 restrains let-7c availability, promoting the symmetric division and maintenance of breast CSCs via the activation of ER-Wnt signaling [79].

In contrast to $\mathrm{H} 19$, miR-146a, via indirect upregulation of let-7c, promotes asymmetric division and inhibits the self-renewal ability of breast CSCs by downregulating Wnt signaling [80]. Through inhibition of the cyclin D1/Akt1/Wnt1 signaling pathway, let-7d also inhibits CSC properties and exerts synergistic effects with radiotherapy to inhibit breast CSC self-renewal [81].

A similar role of let-7b in controlling the self-renewal of breast CSCs was also suggested by a study showing that Matrine, a natural product extracted from the root of Sophora flavescens Ait, induced cisplatin hypersensitivity by suppressing the expression of Lin28A, resulting in the inactivation of Wnt pathway in a let-7b-dependent manner [82]. 
Paralleling its effects on breast cancer cells, Matrine was also reported to have antitumor properties in other types of cancer through upregulation of let-7b, which inactivates the Wnt/CCND1 signaling pathway and inhibits EMT and lung CSC activities [83]. In esophageal cancer, Wnt activation stimulates the self-renewal of CSC-like cells, which is blocked by the administration of nano-let- $7 \mathrm{~b}$ via direct inhibition of TCF- $4 / \beta$-catenin complex activity to sensitize chemotherapeutic response [84].

In hepatocellular carcinoma cells, the overexpression of let-7a also inhibits the tumorsphereforming ability by inhibition of EMT factors and the Wnt signaling pathway [85]. In NSCLC, oncogenic miR-367 promotes the self-renewal ability of CSC-like cells by degrading E3Ligase Enzyme F-box and WD repeat domain-containing 7 (FBXW7) and repressing let-7c, leading to the activation of Wnt signaling [86]. Attenuation of Wnt/ $\beta$-catenin activity by the tankyrase inhibitor JW74 leads to the induction of let-7 miRNA, which contributes to osteosarcoma cell differentiation [87].

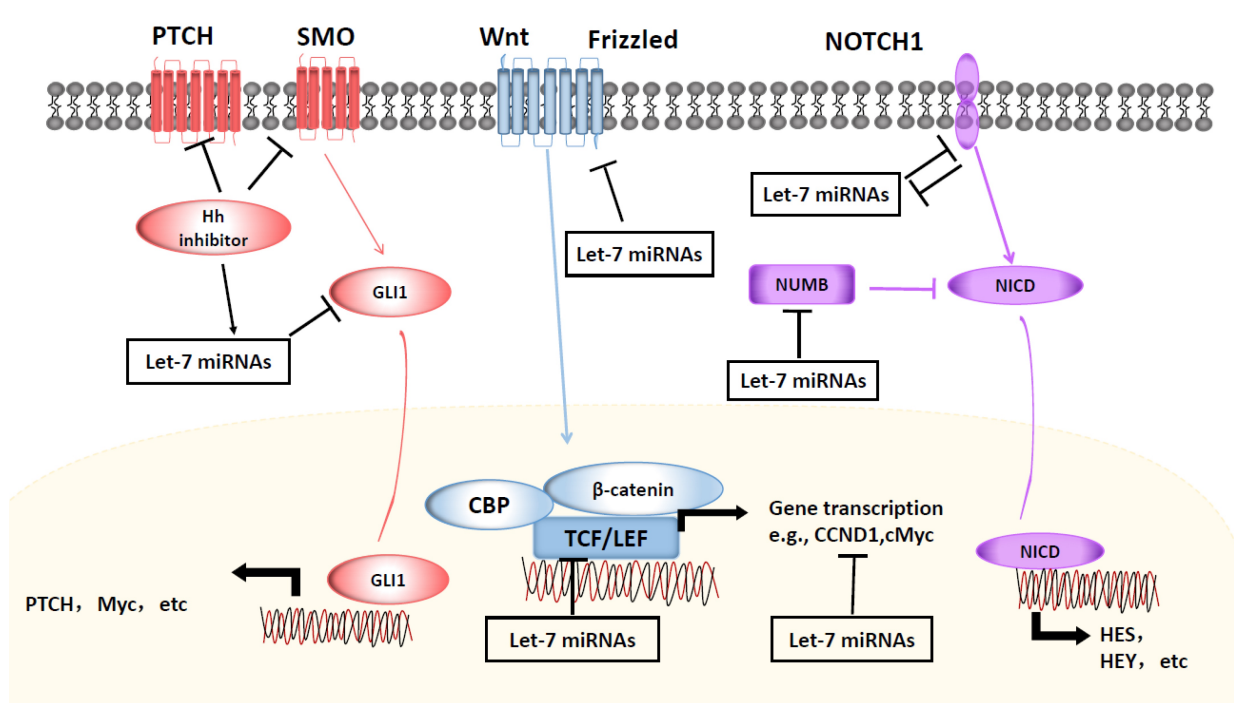

Figure 2. Let-7 miRNAs regulate CSCs through interaction with the Wnt, Hedgehog and NOTCH pathways. Members of Let-7 family of miRNAs interact with receptors and/or down-streaming effector genes of Wnt, Hedgehog and NOTCH pathways to regulate CSC self-renewal, proliferation and differentiation.

\subsection{NOTCH/Hedgehog Signaling}

Aberrant activation of NOTCH signaling is associated with the stemness phenotype of many different tissue malignancies. Let-7 miRNAs play a functional role in the development of human neural progenitors by suppressing HMGA2 and NOTCH to regulates gliogenesis [88]. Recent studies have suggested mutual regulation of miRNAs and NOTCH signaling in multiple tumor cell types (Figure 2).

For example, treatment of pancreatic cancer cells with metformin, an antidiabetic drug, decreased the expression of the CSC markers CD44, EpCAM, EZH2, NOTCH1, NANOG and OCT4 but elevated the expression of miRNAs, including let-7a, let-7b, miR-26a, miR101, miR-200b, and miR-200c in a mouse xenograft model [89]. Conversely, overexpression of NOTCH1 increased the expression of oncogenic miR-21 while decreasing the expression of miR-200b, miR-200c, let-7a, let-7b and let-7c, promoting EMT and a CSC-like phenotype in pancreatic cancer cells [90].

In ER+ breast cancer, miR-129 inhibits estrogen receptor 1 (ESR1)-mediated NOTCH signaling in CSC-like cells by suppressing cyclin D1/DICER1 mediated let-7 maturation, leading to increased NUMB expression to repress NOTCH signaling activity [91].

The hedgehog pathway is involved in embryonic development and maintenance of CSCs through signal transmission via sonic hedgehog (Shh), PTCH1, SMO to activate transcription factor GLI-driven downstream gene responses. As illustrated in Figure 2, 
activation of the hedgehog pathway can suppress the expression of let-7 miRNAs, which promotes CSC properties.

In pancreatic cancer, highly metastatic cancer cells exhibit upregulation of Shh and CSC surface marker expression, including CD133 and CXCR4, associated with lower levels of let-7 expression as compared to parental BxPC-3 cells [92]. In NSCLC, a hedgehog inhibitor promotes sensitization of tumor cells to erlotinib by increasing let-7c but suppressing the expression of CSC-associated genes, including SOX2, NANOG and EpCAM [93].

\subsection{STAT3/NFkB/Cytokines Signaling}

The activation of transcription factors, such as the signal transducer and activator of transcription 3 (STAT3) and NFkB, elicited by pro-inflammatory cytokines, such as IL1, IL6 and IL8, secreted in the tumor microenvironment, promotes tumor epigenetic/phenotypic plasticity reflected by increased mesenchymal signature gene expression and cancer stemness. As illustrated in Figure 3, one of the key mechanisms by which STAT3/NFkB signaling promotes cancer stemness is through their negative regulation of let-7 miRNAs.

In NSCLC, the oncogenic MUC1-C transmembrane protein induces EMT by promoting $\mathrm{NF} K \mathrm{~B}$ p65 binding to Lin28B chromatin to activate Lin28B expression, leading to the suppression of let-7 [94]. As is the case for NFKB, the activation of STAT3 in breast cancer promotes the transcription of Lin28B by directly binding to the Lin28B promoter, resulting in the repression of let-7 expression and concomitant upregulation of the let-7 target, HMGA2 [95].

Similarly, activation of the STAT3/NFKB pathway in breast cancer cells by M1 macrophage secreted pro-inflammatory cytokines elicits Lin28B-let-7-HMGA2 axis to induce CD44+/CD24and ALDH1+ CSCs through activation of EMT [96]. In esophageal cancer cells, elevated let-7c expression following knocking down of lncRNA H19 is reported to repress cell proliferation, migration, invasion as well as EMT and metastasis via inhibition of the STAT3-EZH2- $\beta$-catenin pathway [71].

Overexpression of let-7c, which acts as an upstream suppressor of the Ras/NFkB signal pathway, decreases malignant transformation and acquisition of cancer stem cell-like properties in normal adult skin keratinocytes [97]. In oral cancer cells, ectopic expression of let-7c downregulates stemness and radio- and chemo-resistance through directly targeting IL8 [98]. In breast cancer cells, let-7a directly binds to the $3^{\prime} \mathrm{UTR}$ of the C-C chemokine receptor type 7 (CCR7) to suppress its expression, leading to impaired migration and invasion [99].

Let-7a is also reported to directly inhibit IL6 expression and activation of Src oncoprotein promotes NFKB-Lin28 signaling to inhibit let-7a expression, leading to high level of IL6 production and activation of $\mathrm{NFKB}$, thereby, completing a positive feedback loop to facilitate an epigenetic switch of immortalized breast epithelial cells into a stably transformed CSC-like state [100].

\subsection{MAPK/ERK and PI3K/AKT Signaling}

Receptor tyrosine kinases (RTKs), such as the epidermal growth factor receptor (EGFR) family, are activated by extracellular ligands such as EGF to activate MAPK/ERK (also known as Ras-RAF-MEK-ERK) and PI3K-AKT-mTOR signaling pathways to regulate cell proliferation/self-renewal, survival and differentiation. The Ras small GTPases consist of three major isoforms, including $\mathrm{H}-$, K- and N-Ras. Both $\mathrm{H}$ - and $\mathrm{K}-\mathrm{Ras}$ are targeted by the let-7 family of miRNAs to regulate CSC activities (Figure 3).

Specifically, Lin28A facilitates glioblastoma neurosphere formation through constitutively activating K-Ras and suppressing let-7b and let-7g [101]. In pancreatic cancer, K-Ras blocks let-7i maturation by phosphorylating Lin28B at S243 and promoting Lin28B nuclear translocation [102]. The dietary agents sulforaphane, quercetin and catechins inhibit CSClike activities of pancreatic cancer cells through let-7a induction and K-Ras inhibition [103]. Inhibition of the RAS/MEK pathway decreases the expression of let-7 target gene HMGA2, which is required to maintain EMT and the mesenchymal phenotype [104]. 


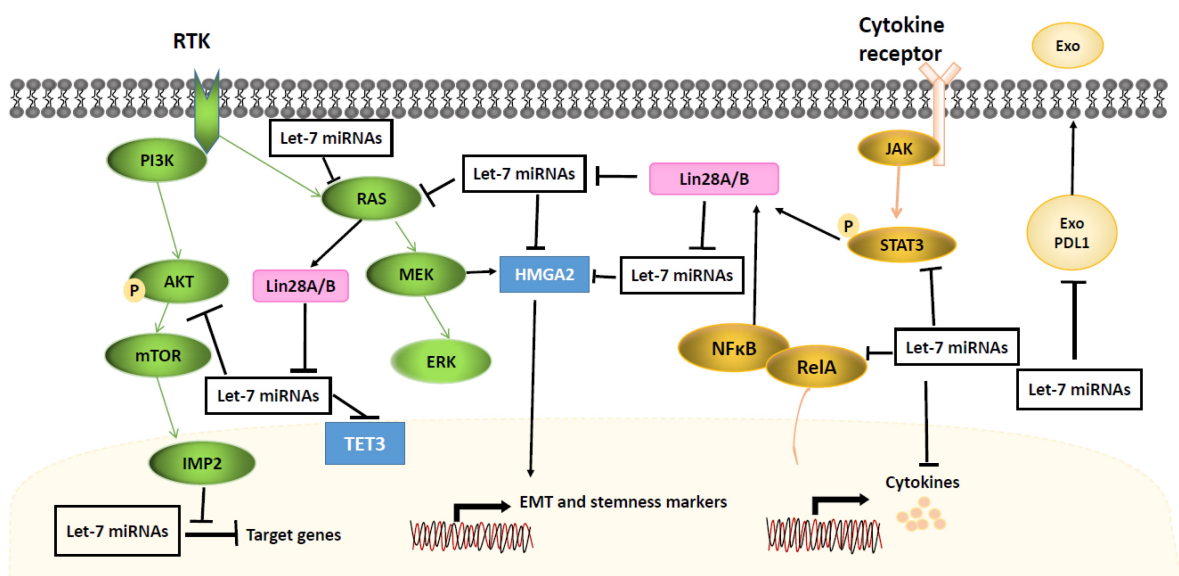

Figure 3. Let-7 miRNAs regulate CSCs via regulation of STAT3/NFKB/cytokine signaling as well as receptor tyrosine kinases (RTKs)-mediated signaling cascades, including the Ras-RAF-MEKERK and PI3K/Akt pathways. Members of Let-7 family of miRNAs interact with the effector genes of JAK-STAT and NFKB to regulate proinflammatory responses, including cytokine production (right part). Let-7 miRNAs, through interaction with down-streaming effectors or target genes of Ras-RAF-MEK-ERK and PI3K/Akt pathways to regulate CSC activities (left part).

In K-Ras-driven lung cancer, increased Lin28B expression induces CD44+/CD326+ CSC-like cells by decreasing let-7 miRNAs and promoting AKT activity [105]. In Table 1, we listed most of the target genes involved in many different signaling cascades that are directly or indirectly repressed by let-7 family of miRNAs in various cancer types.

Table 1. Directly or indirectly repressed genes by the let-7 family of miRNAs in various cancer types

\begin{tabular}{|c|c|c|c|c|c|c|}
\hline miRNA & Cancer & Signalling Pathways & Target Genes & Regulated by & Stemness & References \\
\hline Let-7a & Hepatocarcinoma & Wnt $/ \beta$-catenin & Direct TCF-4 & $\mathrm{NA}$ & EMT, sphere formation & [85] \\
\hline Let-7c & NSCLC & Wnt $/ \beta$-catenin & Indirect TCF-4 and Wnt1 & mir-367,FBXW7 & ALDH, CD133, Sphere formation & [86] \\
\hline Let-7b & NSCLC & Wnt $/ \beta$-catenin & Indirect CCND1 and TCF-4 & Matrine & KLF4, CD133 & [83] \\
\hline Let-7 & Osteosarcoma & Wnt $/ \beta$-catenin & NA & JW74 & c-myc & [87] \\
\hline nano Let-7b & Esophageal cancer & Wnt $/ \beta$-catenin & Direct TCF-4 & NA & ALDH, CD133 & [84] \\
\hline Let-7a, $\mathrm{f}$ & Breast cancer & Wnt/ $\beta$-catenin & Correlation & Lin28B, $\beta$-catenin & ALDH & [76] \\
\hline Let-7c & Breast cancer & Wnt $/ \beta$-catenin & Direct TCF-4 & NA & ALDH, SOX2, NANOG, OCT4 & [77] \\
\hline Let-7c & Breast cancer & Wnt/ $\beta$-catenin & Direct TCF-4 & H19 & ALDH & [79] \\
\hline Let-7d & Breast cancer & Wnt $/ \beta$-catenin & Direct CCND1 & NA & OCT3/4, NANOG, SOX2, ALDH & [81] \\
\hline Let-7c & Breast cancer & Wnt $/ \beta$-catenin & Direct ERa & $\mathrm{NA}$ & ALDH & {$[78]$} \\
\hline Let-7c & Breast cancer & Wnt/ $\beta$-catenin & Direct TCF-4 & mir-146a, Lin28A, H19 & ALDH & [80] \\
\hline Let-7b & Breast cancer & Wnt $/ \beta$-catenin & Indirect CCND1, TCF-4 & Matrine, Lin28A & CD133, KLF4 & [82] \\
\hline Let-7 & Breast cancer & STAT3/NFkB & Indirect HMGA2 & M1 & ALDH,CD44+/CD24-, KLF4,NANOG & [96] \\
\hline Let-7c & Keratinocytes & STAT3/NFKB & Indirect k-Ras, p-RelA & Arsenite & $\mathrm{K} 5, \mathrm{CD} 34$ & [97] \\
\hline Let-7 & NSCLC & STAT3/NFkB & Indirect HMGA2, TGFBR3 & MUC1-C, NFkB, Lin28b & Sphere formation & [94] \\
\hline Let-7c & Oral cancer & STAT3/NFKB & Direct IL8 & NA & ALDH, CD44+ & [98] \\
\hline Let-7 & Breast cancer & Metabolism & Direct HIF-1 $\alpha$, indirect PDK1 & H19 & $\mathrm{ALDH}, \mathrm{OCT} 4$ & [106] \\
\hline Let-7 & Hepatocarcinoma & Metabolism & Indirect SREBP-1 & $\operatorname{Lin} 28 \mathrm{~A} / \mathrm{B}$ & Fatty acid synthesis, tumor growth & [107] \\
\hline Let-7 & Neuroblastoma & Metabolism & NA & DMFO, Lin28B, MYCN & Neurosphere formation & {$[108,109]$} \\
\hline Let-7c, d & Breast cancer & Metabolism & Indirect PDK1, p-PDH & CAIX, Lin28B, NFKB & ALDH, NANOG & [110] \\
\hline Let- $7 \mathrm{~b}, \mathrm{~g}$ & Glioblastoma & MAPK/PI3K & Correlation p-MAPK & Lin28A, K-Ras & CD133, SOX2, Nestin, OLIG2, OCT4, Snail & [101] \\
\hline Let-7a, f, g & NSCLC & MAPK/PI3K & Indirect pAKT, cMYC,VEGFA & Lin28B & CD44+/CD326+, EMT & [105] \\
\hline Let-7a 6 & Pancreatic cancer & MAPK/PI3K & HMGA2 & MEK & EMT & [104] \\
\hline Let-7i & Pancreatic cancer & MAPK/PI3K & Direct TET3 & $\mathrm{K}-\operatorname{Ras} \rightarrow \operatorname{Lin} 28 \mathrm{~B}$ & OCT4, NANOG, SOX2, CD133 & [102] \\
\hline Let-7a & Pancreatic cancer & MAPK/PI3K & $\mathrm{K}$-Ras & Green tea catechins (GTC) & ALDH, sphere formation & [103] \\
\hline Let-7 & Pancreatic cancer & Hedgehog & Correlation Shh & NA & CD133, CXCR4, sphere formation & [92] \\
\hline Let-7c & NSCLC & Hedgehog & NA & Hedgehog inhibitor & SOX2, NANOG, EPCAM & [93] \\
\hline Let-7b & Breast cancer & NOTCH & Direct NUMB & mir- $129 \rightarrow$ ESR $1 \rightarrow$ DICER1 & CD44+/CD24-, ALDH & [91] \\
\hline Let-7a & Breast cancer & EMT & Indirect ERa, pS2, CCND1 & NA & ALDH, SP population & [21] \\
\hline Let-7d & Oral cancer & EMT & Indirect Twist, Snail, CDH1, Fibronectin 1 & $\mathrm{NA}$ & ALDH & [22] \\
\hline Let-7 & Ovarian cancer & EMT & NA & Snail & CD117, CD133, CD44, sphere formation & [24] \\
\hline Let-7 & Ovarian cancer & EMT & Correlation & Correlation & CD44, CD117, CD133, OCT4, NANOG,Lin28A, HMGA2 & [25] \\
\hline Let-7 & Pancreatic cancer & EMT & Correlation & LncRNA ROR & 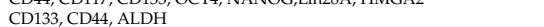 & [72] \\
\hline Let-7a & Tongue squamous cell carcinoma & EMT & Direct HMGA2 & H19 & CDH1, CDH2, Vimentin, Snail, Zeb1, Twist1 & [23] \\
\hline Let-7b & Gastric cancer & Pluripotency transcription factor & Direct c-myc & $\mathrm{NA}$ & c-myc & [17] \\
\hline Let-7 & Prostate cancer & Pluripotency transcription factor & Direct HMGA2 & Lin28B & SOX2, CD44, CD133 & [19] \\
\hline Let-7 & Bladder cancer & Pluripotency transcription factor & Indirect SOX2 & COX2, PGE2 & SOX2, OCT4, NANOG, CD24, CD133 & [18] \\
\hline Let-7 & Pancreatic cancer & Pluripotency transcription factor & Correlation & Correlation & CD44+ /CD133+ /EpCAM+ cells, Snail, OCT4, NANOG, SOX2, EZH2 & [16] \\
\hline
\end{tabular}

\section{The Let-7/Lin28 Axis in Regulation of Stem Cell Metabolism}

Earlier studies using transgenic mouse models demonstrated a role for the let-7/Lin28 axis in regulation of glucose metabolism. Transgenic mice expressing Lin28A have increased body size, crown-rump length and delayed onset of puberty due to increased glucose metabolism and insulin sensitivity [111]. This increased glucose metabolism is attributed to Lin28A/B-mediated repression of let-7, leading to an insulin-sensitized state through activation of the insulin-PI3K-mTOR pathway [111]. 
Such a role of the let-7/Lin28 axis in regulation of glucose metabolism is further demonstrated in transgenic mice with muscle-specific loss of Lin28A or overexpression of let-7, which results in insulin resistance, hyperglycemia and impaired glucose tolerance [112]. In addition to a role in regulating glucose metabolism during development, recent studies indicated that Lin28A and its closely related paralog, Lin28B, play critical roles in regulating pluripotent stem cells (PSCs).

Lin28, along with OCT4, SOX2, and NANOG, acts as important tissue factors to reprogram human somatic fibroblasts into pluripotent stem cells [113], which exist in a highly oxidative "naïve" state and a more glycolytic "primed" state $[114,115]$. Overexpression of Lin28A and Lin28B both enhance the derivation efficiency of induced PSCs (iPSCs), while loss of endogenous Lin28A/B reduces reprogramming efficiency and traps the derived mouse iPSCs in a more "naïve" oxidative state, suggesting that Lin28A and Lin28B facilitate transition from naïve to primed pluripotency [116].

As reflected by their multipotent tumor cell state, CSCs exhibit a remarkable ability to adapt their metabolism to survive and proliferate under adverse environment conditions, such as hypoxia, acidosis, and nutrient starvation. As illustrated in Figure 4, recent studies have provided strong evidence that the let-7/Lin28 axis regulates cancer progression and CSC activity through metabolic modulation.

In breast cancer, Lin28A and Lin28B enhance, whereas let-7 suppresses, aerobic glycolysis through regulation of pyruvate dehydrogenase kinase 1, or PDK1, in a hypoxia- or hypoxia-inducible factor-1 (HIF-1)-independent manner, suggesting direct regulation of the Lin28/let-7 axis in the modulation of glycolytic metabolism even at ambient oxygen levels [106]. PDK1, by phosphorylating pyruvate dehydrogenase (PDH) to inhibit its enzymatic function of promoting glucose flux to mitochondrial oxidative phosphorylation (OXPHOS), serves as a gatekeeper of aerobic glycolysis.

Interestingly, PDK1 is reported to be enriched in ALDH+ CSCs, and the depletion of PDK1 diminishes the sphere-forming ability and tumor growth by abrogating ALDH+ CSCs [117]. This increased PDK1 activity in BCSCs is linked to elevated expression of LncRNA H19, which acts as a molecular sponge sequestering let-7 miRNA, leading to the activation of HIF1 $\alpha$ to enhance its downstream target PDK1 expression [117].

The expression of carbonic anhydrase IX (CAIX), a pH regulator and hypoxia marker, is correlated with poor prognosis and increased metastases in breast cancer [110]. In CAIX-suppressed breast cancer cells, let-7 miRNAs are upregulated while Lin28 protein levels decreased, leading to suppressed PDK1 activity and attenuated phosphorylation of PDH at Ser-232, which results in increased OXPHOS but reduced glycolysis and lactate production [110]. Thus, modulation of the Lin28/let-7 axis regulates tumor glycolytic metabolism through direct or indirect regulation of PDK1 activity, which directs glucose influx into aerobic glycolysis.

As mentioned above, overexpression of Lin28 and/or downregulation of let-7 miRNAs has emerged as an oncogenic driver in many different cancers, which promotes cancer stemness and poor patient outcome. The oncometabolite polyamine modulates the expression of eukaryotic translation initiation factor eIF-5A, which serves as a direct regulator of the Lin28/let-7 axis [108]. In neuroblastoma cells, Difluoromethylornithine (DFMO), a drug targeting ornithine decarboxylase, the rate-limiting enzyme of polyamine biosynthesis, reduces Lin28B protein expression while increasing let-7 miRNA, leading to the inhibition of glycolytic metabolism and decreased neurosphere forming activity [109].

In addition to glucose metabolism, cancer cells also rely on de novo fatty acid biosynthesis to maintain rapid cell proliferation and tumor growth [118]. Elevated expression of Lin28A/B enhances de novo fatty acid synthesis to promote cancer progression via SREBP-1 [107]. By direct association with the mRNAs of both SREBP-1 and SCAP, Lin28A/B enhances the translation and maturation of SREBP-1, which, in turn, accelerates metabolic conversion of saturated and unsaturated fatty acids and protects cancer cells from lipotoxicity [107]. 


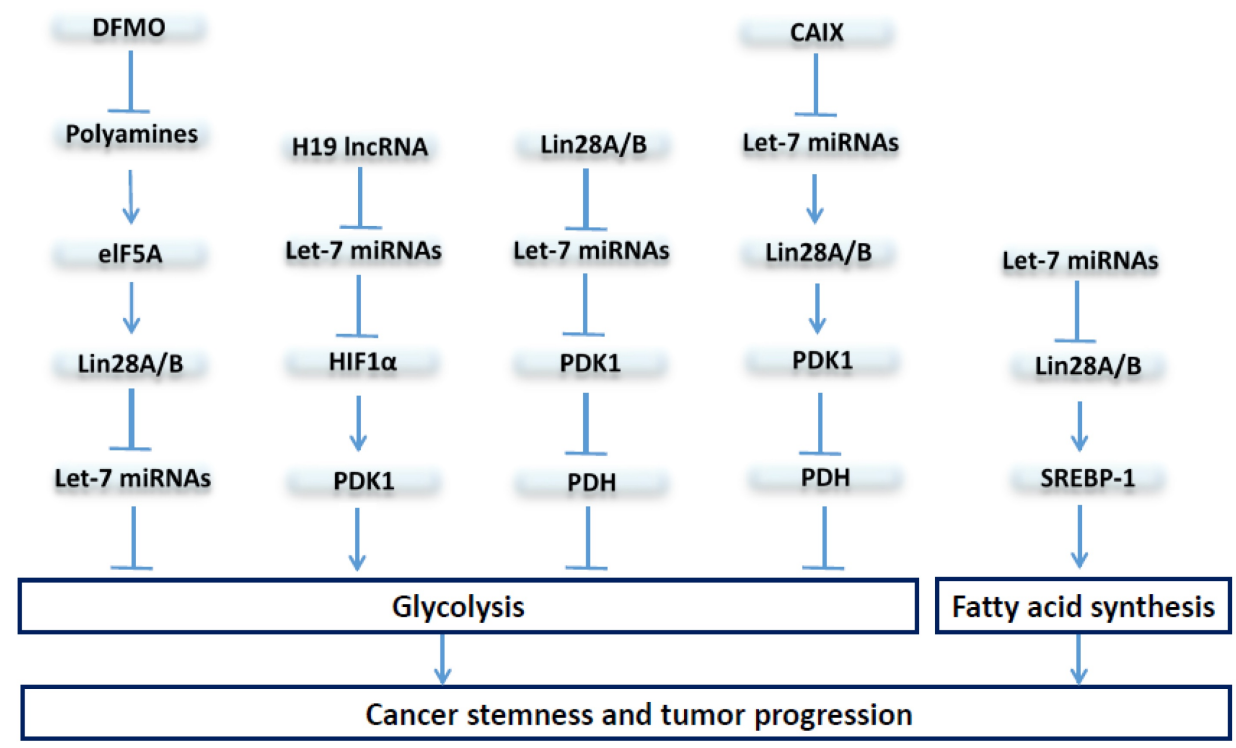

Figure 4. The let-7/Lin28 axis regulates CSCs through modulation of glucose and fatty acid metabolism. Lin28A and Lin28B enhance, whereas let-7 suppresses, aerobic glycolysis or fatty acid synthesis mainly through regulation of the PDK1/PDH enzymatic cascade or SREBP-1 to impact CSC activity and tumor progression.

The inhibition of Lin28B impairs cell growth and amino acid metabolism in acute myeloid leukemia by de-repressing let-7a, although the downstream molecular mechanisms are not known [119]. Thus, targeting Lin28 and/or restoring let-7 expression, by inhibiting tumor metabolic activities in CSCs, may provide potential therapeutic strategies for cancer treatment.

\section{Let-7 miRNAs as Potential Therapeutic Agents Targeting CSCs}

As mentioned above, the let-7 family of miRNAs have been extensively documented to serve as a class of tumor suppressor miRNAs to inhibit stem cell function in normal and cancerous tissues, and the enhanced expression of let-7 inhibits the maintenance of CSCs, thus, inhibiting tumor growth and progression. In fact, let-7 miRNA replacement therapy has now emerged as a powerful strategy to inhibit tumor growth and progression and overcome treatment resistance.

Three approaches to harness tumor suppressor miRNAs, such as let-7, for therapeutic purposes have been described, including: (1) the utilization of recombinant lentiviruses or adenoviruses expressing let-7 miRNAs in tumor cells as a type of gene therapy, (2) the administration of small molecules that epigenetically enhances endogenous let-7 expression, and (3) the administration of synthetic let-7 miRNA mimics in conjugation with nanoparticle-based delivery.

\subsection{Let-7 Replacement Therapy Employing Plasmid and Virus-Based Expression Systems}

To restore let-7 miRNA expression, a plethora of studies have used plasmid and virusbased vector systems to either directly express let-7 or express regulatory proteins capable of upregulating let-7 miRNA expression in tumor cells. The expression of let-7g is extremely low in hepatocellular carcinoma (HCC) and re-expression of let-7g miRNA in HCC cells inhibited tumor cell proliferation and migration via inhibition of K-Ras/HMGA2/Snail axis [120].

Moreover, the intra-tumoral injection of plasmid expressing let-7g inhibited tumor growth of HCC cells in nude mice [120]. Stable expression of let-7a in human breast cancer cells delivered by lentivirus infection significantly reduced mammosphere formation and tumorigenicity when implanted in immunodeficient mice [14]. Similarly, in ER+ breast cancer cells, lentivirus-mediated let-7c expression has been shown to decrease tumorigenicity of estrogen-treated BCSCs in vivo by suppression of Wnt signaling [78]. Over-expression of CDX2, a transcriptional factor called caudal type homeobox 2 in MCF7 
breast cancer cells alleviates tumor growth and micro-metastasis by up-regulating let- $7 \mathrm{~b}$ and inhibiting COL11A1 expression [121].

Although overexpression of let-7 miRNAs in cancer cells has been shown to inhibit tumorigenicity and progression when implanted in mice, several studies have applied different virus-based systems for the direct delivery of let-7 miRNAs locally or intratumorally. For example, intranasal administration of recombinant adenovirus expressing let-7a RNA hairpin has been shown to significantly reduce tumor formation in vivo in the lungs of animals that express a G12D activating mutation for the K-Ras oncogene [122].

The ectopic expression of let-7g in K-Ras(G12D)-expressing murine lung cancer cells induced cell cycle arrest and cell death and overexpression of let-7g by inducible lentiviral vectors led to significant growth reduction in tumor xenografts [123]. A single dose of intratumor injection of lentiviruses expressing let-7c is capable of suppressing the tumor growth of prostate cancer xenografts [124].

\subsection{Restoration of Endogenous Let-7 Expression to Enhance Treatment Responses}

Current frontline therapies frequently fail to eradicate cancer due to their failure to eliminate cancer-stem-like cells, which confer resistance to traditional chemo/radiation or molecularly targeted therapies, promoting metastasis and cancer relapse. As shown in Table 2, therapyinduced cancer stemness by widely used chemotherapeutic or molecularly targeted agents has been reported to be abolished by restoration of let-7 miRNA expression in various types of cancer, including breast cancer [82], NSCLC [83], head and neck cancer [15], ovarian cancer $[24,25]$ and others. In pancreatic cancer, Gemcitabine-resistant tumor cells exhibit higher CSC marker CD133 expression associated with lower levels of Let-7 [92,125].

Combined use of gemcitabine with thiostrepton, a natural cyclic oligopeptide antibiotic, synergistically inhibits sphere formation of NSCLC by elevating miR-98 [126]. In ER+ breast cancer, tamoxifen acts as an estrogen competitive antagonist, and Let-7c enhances the anticancer functions of tamoxifen and reduces the proportion of breast CSCs [78]. The DNA alkylating agent temozolomide (TMZ) is one of the current standard treatment for glioblastoma patients. Dovitinib, a multi-kinase inhibitor, enhances TMZ-induced cytotoxicity through modulation of Lin28/let-7/HMGA2 axis in vitro and in vivo [127].

In NSCLC, combined use of hedgehog inhibitor GDC-0449 leads to sensitization to erlotinib, an EGFR-TKI inhibitor through upregulating let-7c [93]. Let-7 restoration also exerts synergistic effects with radiotherapy to target stem-like cells in breast cancer [81], oral squamous cell carcinoma [98], and melanoma [128]. Both Let-7b [17,84] and let-7d [18,22], are involved in multiple drug sensitization in several preclinical studies, suggesting that tumor delivery of let-7 may be a promising therapeutic approach to enhance drug responses. In head and neck squamous cell carcinoma (HNSCC), the overexpression of let-7a/b miRNAs in combination with CTLA-4 antibody promotes anticancer immunity by accelerating PD-L1 degradation [129].

Table 2. Induction of Let-7 miRNAs to overcome therapeutic resistance by targeting CSCs.

\begin{tabular}{|c|c|c|c|c|}
\hline Therapy & miRNAs & Regulated Stemness Markers & Functions of miRNAs in Therapeutic Sensitization & References \\
\hline \multirow{4}{*}{ Mutiple drugs } & Let-7 & CD133, CD24 & COX2 inhibitor $\rightarrow$ Let $-7 \rightarrow$ SOX2 $\rightarrow$ CD133, CD44 & [18] \\
\hline & Let-7d & ALDH & Let-7d $\rightarrow$ EMT $\rightarrow$ ALDH & [22] \\
\hline & Nano Let-7b & CD133, ALDH & Nano Let-7b $\rightarrow$ TCF4/Wnt $\rightarrow$ CD133, ALDH & [84] \\
\hline & Let-7b & EMT & Let- $7 \mathrm{~b} \rightarrow \mathrm{cmyc} \rightarrow$ EMT & [17] \\
\hline Temozolomide & Let-7 & Sphere formation & Dovitinib $\rightarrow$ Let-7/Lin28a/HMGA2 $\rightarrow$ pSTAT3 $\rightarrow$ Sphere formation & [127] \\
\hline Tamoxifen & Let-7c & ALDH & Let-7c $\rightarrow$ TCF4 $/$ Wnt $\rightarrow$ ALDH & [78] \\
\hline Erlotinib/Cisplatin & Let-7 & SOX2, NANOG, EpCAM & Hedgehog inhibotor $\rightarrow$ Let-7 $\rightarrow$ EMT $\rightarrow$ SOX2, NANOG,EpCAM & [93] \\
\hline \multirow[t]{2}{*}{ Cisplatin } & Let- $7 \mathrm{~b}$ & CD133 & Matrine $\rightarrow$ Let- $7 \mathrm{~b} /$ Lin28A $\rightarrow$ CCDN1/Wnt $\rightarrow$ CD33 & [82] \\
\hline & Let-7 & CD133, CD44, CD117 & shSnail/HGSOC $\rightarrow$ Let-7 $\rightarrow$ CD133, CD44, CD117 & [24] \\
\hline Cisplatin/Radiation & Let-7c & ALDH, CD44 & Let-7c $\rightarrow$ IL8 $\rightarrow$ ALDH, CD44 & [98] \\
\hline \multirow{2}{*}{ Radiation } & Let-7d & ALDH & Let-7d $\rightarrow$ CCND1/Wnt $\rightarrow$ ALDH & [81] \\
\hline & Let-7 & Sphere formation & Let-7/Lin28B $\rightarrow \gamma \mathrm{H} 2 \mathrm{AX}$ & [128] \\
\hline \multirow[t]{2}{*}{ Gemcitabine } & $\operatorname{miR}-98$ & CD133 & Thiostrepton $\rightarrow$ miR-98 $\rightarrow$ CD133 & [126] \\
\hline & Let-7 & CD133 & Hedgehog inhibitor $\rightarrow$ Let-7 $\rightarrow$ CD133 & {$[92,125]$} \\
\hline CTLA-4 antibody & Let-7a/b & Wnt/ $\beta$-catenin & Let-7a/b $\rightarrow$ TCF- $4 \rightarrow \beta$-catenin/STT3 $\rightarrow$ PDL1 degradation & [129] \\
\hline
\end{tabular}




\subsection{Let-7 miRNAs Encapsulated in Extracellular Vesicles for Potential Cancer Therapy}

Secreted miRNAs encapsulated in extracellular vesicles (EVs) play an important role in cell-cell communications. Exosomes are a subclass of EVs with the size ranging from 30 to $150 \mathrm{~nm}$ in diameter containing proteins, RNAs, DNAs, lipids, and metabolites, which mediate juxtacrine/paracrine signaling in the tumor microenvironment $[130,131]$. Recent studies have indicated a role of exosomal let-7 miRNAs with strong antitumor activities. In non-small-cell lung cancer (NSCLC), let-7e encapsulated in serum exosomes suppresses the metastatic activity of NSCLC cells by inhibiting the SUV39H2/LSD1/CDH1 axis [132].

In pancreatic cancer, exosome secretion from cancer cells promotes the recruitment of pancreatic stellate cells (PSCs) to enhance the formation of distant metastases. This effect is mediated by the transfer of exosomal protein Lin28B, a protein that suppressing let-7 maturation, to PSCs to activate the Lin28B/let-7/HMGA2/PDGF $\beta$ signaling cascade [133]. Docosahexaenoic acid (DHA), a long-chain omega-3 polyunsaturated fatty acid with known anticancer properties, promotes exosome secretion and increased exosomal miRNAs, including let-7a, resulting in the inhibition of breast cancer angiogenesis [134].

In a metastatic gastric cancer cell line called AZ-P7a, exosomal release of let-7 miRNAs into the extracellular environment is significantly increased as compared to non-metastatic gastric cancer cells. This increased exosomal transport of let-7 miRNAs is thought to result in depletion of these tumor suppressor miRNAs in the cells, thereby maintaining their invasiveness and metastatic activity [135].

\subsection{Let-7 Replacement Therapy Using Synthetic Let-7 miRNA Mimics}

Use of miRNA mimics is an effective means to restore the normal function of tumor suppressive miRNAs, including let-7 miRNAs. Transfection of chemically synthesized, double-stranded let-7 mimics into the cytoplasm of tumor cells has emerged as a potential strategy for cancer gene therapy. Intratumoral injection of let-7a mimics coupled with lipid vector lipofectamine 2000 has been shown to retard tumor growth in a glioma xenograft model [136].

Similarly, synthetic let-7b mimics intratumorally delivered into H460 lung tumor xenograft model successfully silenced let-7 targeted genes and repress tumor growth [137]. Transfection of Let- $7 \mathrm{~b}$ mimics into gastric tumor cells also attenuate cisplatin resistance and tumor growth by targeting AURKB [138], and HepG2 cells transfected with let-7b mimics display decreased tumorigenic potential through the upregulated expression of p21 [139].

Let-7e expression was found to be significantly reduced in cisplatin-resistant human epithelial ovarian cancer (EOC) cells, and the overexpression of let-7e by transfection of let-7e Agomir, a type of chemically modified double-strand miRNA mimics, reduces the expression of cisplatin-resistance-related proteins, including EZH2 and cyclin D1, and reverses cisplatin resistance when injected locally into EOC xenograft tumors [140].

Despite intensive studies indicating a role of let-7 family of miRNAs as tumor suppressors, the expression of hsa-let-7g (also known as miR-let-7g or let-7g) and its roles in cancer are context-dependent. For example, let-7g exerts anti-tumor effects in gastric cancer and increases the sensitivity of gastric cancer cells to oxidative stress by inhibiting the activation of DNA damage responses [141]. However, in osteosarcoma, patients with higher expression of let-7g displayed a poorer prognosis and lower survival rate, and the overexpression of let-7g promoted the occurrence of osteosarcoma by down-regulating HOXB1 and activating the NFkB pathway [142].

A major challenge in RNA-based cancer therapies is the lack of safe and reliable means for specific delivery of miRNAs to cancer tissues with low cytotoxicity to normal cells. Tremendous progress has been made in restoring let-7 tumor suppressor miRNA function using let-7 miRNA mimics coupled with nanoparticle-based delivery systems, which have been shown to reduce tumor growth successfully in several animal studies [143-145].

In a K-Ras-activated autochthonous mouse model of NSCLC, synthetic let-7b mimics conjugated with neural lipid emulsions (NLE) was systemically delivered to lung via intravenous administration, leading to reduced tumor burden [146]. Dendrimer-based 
polymeric vectors are another form of non-viral vectors with low toxicity and high delivery potency. When administered to a MYC-driven liver tumor model by IV injection, modular degradable dendrimer nanoparticles carrying let-7g miRNA mimic have been shown to inhibit tumor growth and dramatically extended mouse survival [147].

A form of nanocarriers called PEG5k-VE4-DET20 nano-assemblies is also used to deliver let-7b mimic and chemotherapy drug paclitaxel in the non-small cell lung cancer (A549) model through intravenous injection, and paclitaxel and let-7b mimic-loaded nano-assemblies markedly potentiated the cytotoxicity of paclitaxel and retarded tumor growth more efficaciously than Taxol alone [148]. Using an aptamer that binds to and antagonizes the oncogenic receptor tyrosine kinase Axl (GL21.T), Esposito et al. showed that synthesized let-7g miRNA conjugated to the GL21.T aptamer reduced tumor growth in a xenograft model of lung adenocarcinoma [149].

\section{Concluding Remarks}

Let-7, one of the best studied miRNA families, plays critical roles in controlling various biological processes, including self-renewal, proliferation, differentiation, apoptosis and the cellular metabolism through the regulation of a plethora of target genes and signaling pathways. Let-7 miRNAs generally function as tumor suppressors to target multiple oncogenes, including RAS, HMGA2, c-Myc and CCND1. Let-7 miRNAs also function as important immune regulators to control cytokine- and chemokine-mediated inflammatory responses.

As the let-7 family members of miRNAs share a common seed sequence, localizing at nucleotide 2 to 8 in their $5^{\prime}$ ends, which is pivotal for target mRNA recognition [8], we predict that individual members of let-7 miRNAs have shared or interchangeable functions in repressing their target genes to inhibit CSC activities.

As a well-recognized signaling node to regulate cancer stemness, Lin28 and let-7 miRNAs form a double negative feedback loop to control tumorigenesis, cancer progression and therapeutic resistance. In more than $15 \%$ of tissue malignancies, either Lin28A or Lin28B is reactivated while let-7 is repressed, resulting in the elevated expression of let-7 target genes as well as alterations in tumor cell metabolism.

Current evidence for the Lin28/let-7 axis in regulation of CSC metabolism centers on the glucose metabolism especially aerobic glycolysis, which highlights a role of this axis in the modulation of glycolysis through direct or indirect regulation of PDK1. Although a few studies indicated a role of Lin $28 /$ let- 7 axis in the regulation of the amino acid and lipid metabolisms, future studies need to decipher the underlying mechanisms by which this axis regulates the metabolism of amino acids and lipids in cancer.

The roles of let-7 miRNAs in the development and diseases, particularly in cancer, have made this family of miRNAs attractive candidates for the development of cancer therapeutics. One of the greatest challenges for RNA-based cancer therapy is to design suitable RNA delivery vehicles to achieve specific and safe delivery of therapeutic miRNAs or miRNA mimics into tumor tissues while avoiding potential toxicities and off-target effects. In this regard, several preclinical nanoparticle-based platforms have been developed to deliver miRNA mimics to tumor tissues with considerable efficacy and low toxicity [150]. For example, MRX34, a miR-34 mimic encapsulated in a lipid carrier (developed by Mirna Therapeutics), has the advantage to become positively charged in the acidic tumor microenvironment, which allows the adherence of MRX34 specifically to tumor cells [151]. In a mouse xenograft model treated with MRX34 nanoparticles by intravenous injection, miR-34 was found to accumulate in tumor tissues, leading to significant tumor regression [150,151]. In 2013, MRX34 was tested in a multicenter phase I trial in patients with various cancers, and a portion of these patients achieved prolonged partial responses or stable disease at the end of trial [150]. However, due to immunerelated adverse effects resulting in patient deaths, this trial was prematurely terminated [150]. As recent studies have identified a role of let-7 in regulating CD8 T cell differentiation and function [152,153], future studies in the development of let-7 based RNA therapeutics need to consider the potential immune-related toxicities. 
Author Contributions: Conceptualization: Y.M., M.S.W. and M.L.; Manuscript writing: Y.M. and M.L.; Manuscript review and editing: N.S. and M.S.W. All authors have read and agreed to the published version of the manuscript.

Funding: This work is supported by the NCI grant R35 CA197585 and the Breast Cancer Research Foundation grant BCRF-18-173 to M.S.W.

Institutional Review Board Statement: Not applicable.

Informed Consent Statement: Not applicable.

Data Availability Statement: Not applicable.

Conflicts of Interest: The authors declare no conflict of interest.

\section{References}

1. Ambros, V. A hierarchy of regulatory genes controls a larva-to-adult developmental switch in C. elegans. Cell 1989, 57, 49-57. [CrossRef]

2. Peng, Y.; Croce, C.M. The role of MicroRNAs in human cancer. Signal Transduct. Target. Ther. 2016, 1, 15004. [CrossRef]

3. Alles, J.; Fehlmann, T.; Fischer, U.; Backes, C.; Galata, V.; Minet, M.; Hart, M.; Abu-Halima, M.; Grasser, F.A.; Lenhof, H.P.; et al. An estimate of the total number of true human miRNAs. Nucleic Acids Res. 2019, 47, 3353-3364. [CrossRef]

4. Reinhart, B.J.; Slack, F.J.; Basson, M.; Pasquinelli, A.E.; Bettinger, J.C.; Rougvie, A.E.; Horvitz, H.R.; Ruvkun, G. The 21-nucleotide let-7 RNA regulates developmental timing in Caenorhabditis elegans. Nature 2000, 403, 901-906. [CrossRef] [PubMed]

5. Bussing, I.; Slack, F.J.; Grosshans, H. let-7 microRNAs in development, stem cells and cancer. Trends Mol. Med. 2008, 14, 400-409. [CrossRef]

6. Boyerinas, B.; Park, S.M.; Hau, A.; Murmann, A.E.; Peter, M.E. The role of let-7 in cell differentiation and cancer. Endocr. Relat. Cancer 2010, 17, F19-F36. [CrossRef]

7. Roush, S.; Slack, F.J. The let-7 family of microRNAs. Trends Cell Biol. 2008, 18, 505-516. [CrossRef] [PubMed]

8. Sun, X.; Jiao, X.; Pestell, T.G.; Fan, C.; Qin, S.; Mirabelli, E.; Ren, H.; Pestell, R.G. MicroRNAs and cancer stem cells: The sword and the shield. Oncogene 2014, 33, 4967-4977. [CrossRef] [PubMed]

9. Melton, C.; Judson, R.L.; Blelloch, R. Opposing microRNA families regulate self-renewal in mouse embryonic stem cells. Nature 2010, 463, 621-626. [CrossRef]

10. Sun, X.; Liu, J.; Xu, C.; Tang, S.C.; Ren, H. The insights of Let-7 miRNAs in oncogenesis and stem cell potency. J. Cell. Mol. Med. 2016, 20, 1779-1788. [CrossRef]

11. Balzeau, J.; Menezes, M.R.; Cao, S.; Hagan, J.P. The LIN28/let-7 Pathway in Cancer. Front. Genet. 2017, 8, 31. [CrossRef] [PubMed]

12. Wicha, M.S.; Liu, S.; Dontu, G. Cancer stem cells: An old idea-A paradigm shift. Cancer Res. 2006, 66, 1883-1890. [CrossRef] [PubMed]

13. Luo, M.; Clouthier, S.G.; Deol, Y.; Liu, S.; Nagrath, S.; Azizi, E.; Wicha, M.S. Breast cancer stem cells: Current advances and clinical implications. Methods Mol. Biol. 2015, 1293, 1-49._1. [CrossRef] [PubMed]

14. Yu, F.; Yao, H.; Zhu, P.; Zhang, X.; Pan, Q.; Gong, C.; Huang, Y.; Hu, X.; Su, F.; Lieberman, J.; et al. Let-7 regulates self renewal and tumorigenicity of breast cancer cells. Cell 2007, 131, 1109-1123. [CrossRef]

15. Yu, C.C.; Chen, Y.W.; Chiou, G.Y.; Tsai, L.L.; Huang, P.I.; Chang, C.Y.; Tseng, L.M.; Chiou, S.H.; Yen, S.H.; Chou, M.Y.; et al. MicroRNA let-7a represses chemoresistance and tumourigenicity in head and neck cancer via stem-like properties ablation. Oral Oncol. 2011, 47, 202-210. [CrossRef] [PubMed]

16. Bao, B.; Ali, S.; Ahmad, A.; Li, Y.; Banerjee, S.; Kong, D.; Aboukameel, A.; Mohammad, R.; Van Buren, E.; Azmi, A.S.; et al. Differentially expressed miRNAs in cancer-stem-like cells: Markers for tumor cell aggressiveness of pancreatic cancer. Stem Cells Dev. 2014, 23, 1947-1958. [CrossRef] [PubMed]

17. Yang, X.; Cai, H.; Liang, Y.; Chen, L.; Wang, X.; Si, R.; Qu, K.; Jiang, Z.; Ma, B.; Miao, C.; et al. Inhibition of c-Myc by let-7b mimic reverses mutidrug resistance in gastric cancer cells. Oncol. Rep. 2015, 33, 1723-1730. [CrossRef] [PubMed]

18. Ooki, A.; Del Carmen Rodriguez Pena, M.; Marchionni, L.; Dinalankara, W.; Begum, A.; Hahn, N.M.; VandenBussche, C.J.; Rasheed, Z.A.; Mao, S.; Netto, G.J.; et al. YAP1 and COX2 Coordinately Regulate Urothelial Cancer Stem-like Cells. Cancer Res. 2018, 78, 168-181. [CrossRef]

19. Lovnicki, J.; Gan, Y.; Feng, T.; Li, Y.; Xie, N.; Ho, C.H.; Lee, A.R.; Chen, X.; Nappi, L.; Han, B.; et al. LIN28B promotes the development of neuroendocrine prostate cancer. J. Clin. Investig. 2020, 130, 5338-5348. [CrossRef] [PubMed]

20. Mani, S.A.; Guo, W.; Liao, M.J.; Eaton, E.N.; Ayyanan, A.; Zhou, A.Y.; Brooks, M.; Reinhard, F.; Zhang, C.C.; Shipitsin, M.; et al. The epithelial-mesenchymal transition generates cells with properties of stem cells. Cell 2008, 133, 704-715. [CrossRef]

21. Liu, Y.; Li, H.; Feng, J.; Cui, X.; Huang, W.; Li, Y.; Su, F.; Liu, Q.; Zhu, J.; Lv, X.; et al. Lin28 induces epithelial-to-mesenchymal transition and stemness via downregulation of let-7a in breast cancer cells. PLoS ONE 2013, 8, e83083. [CrossRef]

22. Chang, C.J.; Hsu, C.C.; Chang, C.H.; Tsai, L.L.; Chang, Y.C.; Lu, S.W.; Yu, C.H.; Huang, H.S.; Wang, J.J.; Tsai, C.H.; et al. Let-7d functions as novel regulator of epithelial-mesenchymal transition and chemoresistant property in oral cancer. Oncol. Rep. 2011, 26, 1003-1010. [CrossRef] 
23. Kou, N.; Liu, S.; Li, X.; Li, W.; Zhong, W.; Gui, L.; Chai, S.; Ren, X.; Na, R.; Zeng, T.; et al. H19 Facilitates Tongue Squamous Cell Carcinoma Migration and Invasion via Sponging miR-let-7. Oncol. Res. 2019, 27, 173-182. [CrossRef] [PubMed]

24. Hojo, N.; Huisken, A.L.; Wang, H.; Chirshev, E.; Kim, N.S.; Nguyen, S.M.; Campos, H.; Glackin, C.A.; Ioffe, Y.J.; Unternaehrer, J.J. Snail knockdown reverses stemness and inhibits tumour growth in ovarian cancer. Sci. Rep. 2018, 8, 8704. [CrossRef]

25. Chirshev, E.; Hojo, N.; Bertucci, A.; Sanderman, L.; Nguyen, A.; Wang, H.; Suzuki, T.; Brito, E.; Martinez, S.R.; Castanon, C.; et al. Epithelial/mesenchymal heterogeneity of high-grade serous ovarian carcinoma samples correlates with miRNA let-7 levels and predicts tumor growth and metastasis. Mol. Oncol. 2020, 14, 2796-2813. [CrossRef]

26. Zhu, M.; Zhang, C.; Chen, D.; Chen, S.; Zheng, H. MicroRNA-98-HMGA2-POSTN signal pathway reverses epithelial-to-mesenchymal transition in laryngeal squamous cell carcinoma. Biomed. Pharmacother. 2019, 117, 108998. [CrossRef] [PubMed]

27. Lee, Y.; Ahn, C.; Han, J.; Choi, H.; Kim, J.; Yim, J.; Lee, J.; Provost, P.; Radmark, O.; Kim, S.; et al. The nuclear RNase III Drosha initiates microRNA processing. Nature 2003, 425, 415-419. [CrossRef] [PubMed]

28. Landthaler, M.; Yalcin, A.; Tuschl, T. The human DiGeorge syndrome critical region gene 8 and Its D. melanogaster homolog are required for miRNA biogenesis. Curr. Biol. 2004, 14, 2162-2167. [CrossRef] [PubMed]

29. Gregory, R.I.; Yan, K.P.; Amuthan, G.; Chendrimada, T.; Doratotaj, B.; Cooch, N.; Shiekhattar, R. The Microprocessor complex mediates the genesis of microRNAs. Nature 2004, 432, 235-240. [CrossRef]

30. Denli, A.M.; Tops, B.B.; Plasterk, R.H.; Ketting, R.F.; Hannon, G.J. Processing of primary microRNAs by the Microprocessor complex. Nature 2004, 432, 231-235. [CrossRef]

31. Hutvagner, G.; McLachlan, J.; Pasquinelli, A.E.; Balint, E.; Tuschl, T.; Zamore, P.D. A cellular function for the RNA-interference enzyme Dicer in the maturation of the let-7 small temporal RNA. Science 2001, 293, 834-838. [CrossRef]

32. Bernstein, E.; Caudy, A.A.; Hammond, S.M.; Hannon, G.J. Role for a bidentate ribonuclease in the initiation step of RNA interference. Nature 2001, 409, 363-366. [CrossRef]

33. Yi, R.; Qin, Y.; Macara, I.G.; Cullen, B.R. Exportin-5 mediates the nuclear export of pre-microRNAs and short hairpin RNAs. Genes Dev. 2003, 17, 3011-3016. [CrossRef] [PubMed]

34. Bohnsack, M.T.; Czaplinski, K.; Gorlich, D. Exportin 5 is a RanGTP-dependent dsRNA-binding protein that mediates nuclear export of pre-miRNAs. RNA 2004, 10, 185-191. [CrossRef] [PubMed]

35. Lund, E.; Guttinger, S.; Calado, A.; Dahlberg, J.E.; Kutay, U. Nuclear export of microRNA precursors. Science 2004, 303, 95-98. [CrossRef] [PubMed]

36. Brennecke, J.; Stark, A.; Russell, R.B.; Cohen, S.M. Principles of microRNA-target recognition. PLoS Biol. 2005, 3, e85. [CrossRef] [PubMed]

37. Mayr, C.; Hemann, M.T.; Bartel, D.P. Disrupting the pairing between let-7 and Hmga2 enhances oncogenic transformation. Science 2007, 315, 1576-1579. [CrossRef] [PubMed]

38. Johnson, S.M.; Grosshans, H.; Shingara, J.; Byrom, M.; Jarvis, R.; Cheng, A.; Labourier, E.; Reinert, K.L.; Brown, D.; Slack, F.J. RAS is regulated by the let-7 microRNA family. Cell 2005, 120, 635-647. [CrossRef] [PubMed]

39. Sampson, V.B.; Rong, N.H.; Han, J.; Yang, Q.; Aris, V.; Soteropoulos, P.; Petrelli, N.J.; Dunn, S.P.; Krueger, L.J. MicroRNA let-7a down-regulates MYC and reverts MYC-induced growth in Burkitt lymphoma cells. Cancer Res. 2007, 67, 9762-9770. [CrossRef]

40. Kumar, M.S.; Lu, J.; Mercer, K.L.; Golub, T.R.; Jacks, T. Impaired microRNA processing enhances cellular transformation and tumorigenesis. Nat. Genet. 2007, 39, 673-677. [CrossRef]

41. Kumar, M.S.; Pester, R.E.; Chen, C.Y.; Lane, K.; Chin, C.; Lu, J.; Kirsch, D.G.; Golub, T.R.; Jacks, T. Dicer1 functions as a haploinsufficient tumor suppressor. Genes Dev. 2009, 23, 2700-2704. [CrossRef] [PubMed]

42. Zhu, D.X.; Fan, L.; Lu, R.N.; Fang, C.; Shen, W.Y.; Zou, Z.J.; Wang, Y.H.; Zhu, H.Y.; Miao, K.R.; Liu, P.; et al. Downregulated Dicer expression predicts poor prognosis in chronic lymphocytic leukemia. Cancer Sci. 2012, 103, 875-881. [CrossRef]

43. Khoshnaw, S.M.; Rakha, E.A.; Abdel-Fatah, T.M.; Nolan, C.C.; Hodi, Z.; Macmillan, D.R.; Ellis, I.O.; Green, A.R. Loss of Dicer expression is associated with breast cancer progression and recurrence. Breast Cancer Res. Treat. 2012, 135, 403-413. [CrossRef] [PubMed]

44. Karube, Y.; Tanaka, H.; Osada, H.; Tomida, S.; Tatematsu, Y.; Yanagisawa, K.; Yatabe, Y.; Takamizawa, J.; Miyoshi, S.; Mitsudomi, T.; et al. Reduced expression of Dicer associated with poor prognosis in lung cancer patients. Cancer Sci. 2005, 96, 111-115. [CrossRef] [PubMed]

45. Merritt, W.M.; Lin, Y.G.; Han, L.Y.; Kamat, A.A.; Spannuth, W.A.; Schmandt, R.; Urbauer, D.; Pennacchio, L.A.; Cheng, J.F.; Nick, A.M.; et al. Dicer, Drosha, and outcomes in patients with ovarian cancer. N. Engl. J. Med. 2008, 359, 2641-2650. [CrossRef]

46. Faggad, A.; Kasajima, A.; Weichert, W.; Stenzinger, A.; Elwali, N.E.; Dietel, M.; Denkert, C. Down-regulation of the microRNA processing enzyme Dicer is a prognostic factor in human colorectal cancer. Histopathology 2012, 61, 552-561. [CrossRef]

47. Shu, G.S.; Yang, Z.L.; Liu, D.C. Immunohistochemical study of Dicer and Drosha expression in the benign and malignant lesions of gallbladder and their clinicopathological significances. Pathol. Res. Pract. 2012, 208, 392-397. [CrossRef]

48. Wu, D.; Tao, J.; Xu, B.; Li, P.; Lu, Q.; Zhang, W. Downregulation of Dicer, a component of the microRNA machinery, in bladder cancer. Mol. Med. Rep. 2012, 5, 695-699. [CrossRef]

49. Grelier, G.; Voirin, N.; Ay, A.S.; Cox, D.G.; Chabaud, S.; Treilleux, I.; Leon-Goddard, S.; Rimokh, R.; Mikaelian, I.; Venoux, C.; et al. Prognostic value of Dicer expression in human breast cancers and association with the mesenchymal phenotype. Br. J. Cancer 2009, 101, 673-683. [CrossRef] 
50. Martello, G.; Rosato, A.; Ferrari, F.; Manfrin, A.; Cordenonsi, M.; Dupont, S.; Enzo, E.; Guzzardo, V.; Rondina, M.; Spruce, T.; et al. A MicroRNA targeting dicer for metastasis control. Cell 2010, 141, 1195-1207. [CrossRef]

51. Iliou, M.S.; da Silva-Diz, V.; Carmona, F.J.; Ramalho-Carvalho, J.; Heyn, H.; Villanueva, A.; Munoz, P.; Esteller, M. Impaired DICER1 function promotes stemness and metastasis in colon cancer. Oncogene 2014, 33, 4003-4015. [CrossRef]

52. Lai, H.H.; Li, J.N.; Wang, M.Y.; Huang, H.Y.; Croce, C.M.; Sun, H.L.; Lyu, Y.J.; Kang, J.W.; Chiu, C.F.; Hung, M.C.; et al. HIF-1alpha promotes autophagic proteolysis of Dicer and enhances tumor metastasis. J. Clin. Investig. 2018, 128, 625-643. [CrossRef] [PubMed]

53. van Kouwenhove, M.; Kedde, M.; Agami, R. MicroRNA regulation by RNA-binding proteins and its implications for cancer. Nat. Rev. Cancer 2011, 11, 644-656. [CrossRef]

54. Viswanathan, S.R.; Daley, G.Q.; Gregory, R.I. Selective blockade of microRNA processing by Lin28. Science 2008, 320, 97-100. [CrossRef] [PubMed]

55. Viswanathan, S.R.; Powers, J.T.; Einhorn, W.; Hoshida, Y.; Ng, T.L.; Toffanin, S.; O’Sullivan, M.; Lu, J.; Phillips, L.A.; Lockhart, V.L.; et al. Lin28 promotes transformation and is associated with advanced human malignancies. Nat. Genet. 2009, 41, 843-848. [CrossRef]

56. Cho, J.; Chang, H.; Kwon, S.C.; Kim, B.; Kim, Y.; Choe, J.; Ha, M.; Kim, Y.K.; Kim, V.N. LIN28A is a suppressor of ER-associated translation in embryonic stem cells. Cell 2012, 151, 765-777. [CrossRef] [PubMed]

57. Nguyen, L.H.; Robinton, D.A.; Seligson, M.T.; Wu, L.; Li, L.; Rakheja, D.; Comerford, S.A.; Ramezani, S.; Sun, X.; Parikh, M.S.; et al. Lin28b is sufficient to drive liver cancer and necessary for its maintenance in murine models. Cancer Cell 2014, 26, 248-261. [CrossRef]

58. Shyh-Chang, N.; Daley, G.Q. Lin28: Primal regulator of growth and metabolism in stem cells. Cell Stem Cell 2013, 12, 395-406. [CrossRef]

59. Newman, M.A.; Thomson, J.M.; Hammond, S.M. Lin-28 interaction with the Let-7 precursor loop mediates regulated microRNA processing. RNA 2008, 14, 1539-1549. [CrossRef]

60. Piskounova, E.; Polytarchou, C.; Thornton, J.E.; LaPierre, R.J.; Pothoulakis, C.; Hagan, J.P.; Iliopoulos, D.; Gregory, R.I. Lin28A and Lin28B inhibit let-7 microRNA biogenesis by distinct mechanisms. Cell 2011, 147, 1066-1079. [CrossRef]

61. Michlewski, G.; Caceres, J.F. Post-transcriptional control of miRNA biogenesis. RNA 2019, 25, 1-16. [CrossRef] [PubMed]

62. Heo, I.; Joo, C.; Cho, J.; Ha, M.; Han, J.; Kim, V.N. Lin28 mediates the terminal uridylation of let-7 precursor MicroRNA. Mol. Cell 2008, 32, 276-284. [CrossRef] [PubMed]

63. Heo, I.; Joo, C.; Kim, Y.K.; Ha, M.; Yoon, M.J.; Cho, J.; Yeom, K.H.; Han, J.; Kim, V.N. TUT4 in concert with Lin28 suppresses microRNA biogenesis through pre-microRNA uridylation. Cell 2009, 138, 696-708. [CrossRef] [PubMed]

64. King, C.E.; Cuatrecasas, M.; Castells, A.; Sepulveda, A.R.; Lee, J.S.; Rustgi, A.K. LIN28B promotes colon cancer progression and metastasis. Cancer Res. 2011, 71, 4260-4268. [CrossRef]

65. Ji, J.; Wang, X.W. A Yin-Yang balancing act of the lin28/let-7 link in tumorigenesis. J. Hepatol. 2010, 53, 974-975. [CrossRef]

66. Degrauwe, N.; Suva, M.L.; Janiszewska, M.; Riggi, N.; Stamenkovic, I. IMPs: An RNA-binding protein family that provides a link between stem cell maintenance in normal development and cancer. Genes Dev. 2016, 30, 2459-2474. [CrossRef]

67. Degrauwe, N.; Schlumpf, T.B.; Janiszewska, M.; Martin, P.; Cauderay, A.; Provero, P.; Riggi, N.; Suva, M.L.; Paro, R.; Stamenkovic, I. The RNA Binding Protein IMP2 Preserves Glioblastoma Stem Cells by Preventing let-7 Target Gene Silencing. Cell Rep. 2016, 15, 1634-1647. [CrossRef]

68. Gabory, A.; Ripoche, M.A.; Le Digarcher, A.; Watrin, F.; Ziyyat, A.; Forne, T.; Jammes, H.; Ainscough, J.F.; Surani, M.A.; Journot, L.; et al. H19 acts as a trans regulator of the imprinted gene network controlling growth in mice. Development 2009, 136, 3413-3421. [CrossRef]

69. Kallen, A.N.; Zhou, X.B.; Xu, J.; Qiao, C.; Ma, J.; Yan, L.; Lu, L.; Liu, C.; Yi, J.S.; Zhang, H.; et al. The imprinted H19 lncRNA antagonizes let-7 microRNAs. Mol. Cell 2013, 52, 101-112. [CrossRef]

70. Peng, F.; Li, T.T.; Wang, K.L.; Xiao, G.Q.; Wang, J.H.; Zhao, H.D.; Kang, Z.J.; Fan, W.J.; Zhu, L.L.; Li, M.; et al. H19/let-7/LIN28 reciprocal negative regulatory circuit promotes breast cancer stem cell maintenance. Cell Death Dis. 2017, 8, e2569. [CrossRef]

71. Chen, M.J.; Deng, J.; Chen, C.; Hu, W.; Yuan, Y.C.; Xia, Z.K. LncRNA H19 promotes epithelial mesenchymal transition and metastasis of esophageal cancer via STAT3/EZH2 axis. Int. J. Biochem. Cell Biol. 2019, 113, 27-36. [CrossRef] [PubMed]

72. Fu, Z.; Li, G.; Li, Z.; Wang, Y.; Zhao, Y.; Zheng, S.; Ye, H.; Luo, Y.; Zhao, X.; Wei, L.; et al. Endogenous miRNA Sponge LincRNA-ROR promotes proliferation, invasion and stem cell-like phenotype of pancreatic cancer cells. Cell Death Discov. 2017, 3 , 17004. [CrossRef] [PubMed]

73. He, F.; Song, Z.; Chen, H.; Chen, Z.; Yang, P.; Li, W.; Yang, Z.; Zhang, T.; Wang, F.; Wei, J.; et al. Long noncoding RNA PVT1-214 promotes proliferation and invasion of colorectal cancer by stabilizing Lin28 and interacting with miR-128. Oncogene 2019, 38, 164-179. [CrossRef] [PubMed]

74. Song, X.; Liang, Y.; Sang, Y.; Li, Y.; Zhang, H.; Chen, B.; Du, L.; Liu, Y.; Wang, L.; Zhao, W.; et al. circHMCU Promotes Proliferation and Metastasis of Breast Cancer by Sponging the let-7 Family. Mol. Ther. Nucleic Acids 2020, 20, 518-533. [CrossRef] [PubMed]

75. Hong, W.; Xue, M.; Jiang, J.; Zhang, Y.; Gao, X. Circular RNA circ-CPA4/let-7 miRNA/PD-L1 axis regulates cell growth, stemness, drug resistance and immune evasion in non-small cell lung cancer (NSCLC). J. Exp. Clin. Cancer Res. 2020, 39, 149. [CrossRef] [PubMed] 
76. Cai, W.Y.; Wei, T.Z.; Luo, Q.C.; Wu, Q.W.; Liu, Q.F.; Yang, M.; Ye, G.D.; Wu, J.F.; Chen, Y.Y.; Sun, G.B.; et al. The Wnt-beta-catenin pathway represses let-7 microRNA expression through transactivation of Lin28 to augment breast cancer stem cell expansion. J. Cell Sci. 2013, 126, 2877-2889. [CrossRef]

77. Sun, X.; Xu, C.; Tang, S.C.; Wang, J.; Wang, H.; Wang, P.; Du, N.; Qin, S.; Li, G.; Xu, S.; et al. Let-7c blocks estrogen-activated Wnt signaling in induction of self-renewal of breast cancer stem cells. Cancer Gene Ther. 2016, 23, 83-89. [CrossRef]

78. Sun, X.; Xu, C.; Xiao, G.; Meng, J.; Wang, J.; Tang, S.C.; Qin, S.; Du, N.; Li, G.; Ren, H.; et al. Breast cancer stem-like cells are sensitized to tamoxifen induction of self-renewal inhibition with enforced Let-7c dependent on Wnt blocking. Int. J. Mol. Med. 2018, 41, 1967-1975. [CrossRef]

79. Wang, M.; Li, Y.; Xiao, G.D.; Zheng, X.Q.; Wang, J.C.; Xu, C.W.; Qin, S.; Ren, H.; Tang, S.C.; Sun, X. H19 regulation of oestrogen induction of symmetric division is achieved by antagonizing Let-7c in breast cancer stem-like cells. Cell Prolif. 2019, 52, e12534. [CrossRef]

80. Liang, R.; Li, Y.; Wang, M.; Tang, S.C.; Xiao, G.; Sun, X.; Li, G.; Du, N.; Liu, D.; Ren, H. MiR-146a promotes the asymmetric division and inhibits the self-renewal ability of breast cancer stem-like cells via indirect upregulation of Let-7. Cell Cycle 2018, 17, 1445-1456. [CrossRef]

81. Sun, H.; Ding, C.; Zhang, H.; Gao, J. Let7 miRNAs sensitize breast cancer stem cells to radiationinduced repression through inhibition of the cyclin D1/Akt1/Wnt1 signaling pathway. Mol. Med. Rep. 2016, 14, 3285-3292. [CrossRef]

82. Li, X.; Liang, T.; Chen, S.S.; Wang, M.; Wang, R.; Li, K.; Wang, J.C.; Xu, C.W.; Du, N.; Qin, S.; et al. Matrine suppression of self-renewal was dependent on regulation of LIN28A/Let-7 pathway in breast cancer stem cells. J. Cell. Biochem. 2020, 121, 2139-2149. [CrossRef]

83. Li, X.; Wang, M.; Du, N.; Liang, T.; Xiao, G.D.; Li, K.; Wang, J.C.; Xu, C.W.; Peng, Z.Y.; Tang, S.C.; et al. Matrine Inhibitory Effect on Self-renewal and Re-sensitization of 5-FU Resistant NSCLC Stem Cells were through Let-7b dependent Downregulation of CCND1. Cell Cycle 2020, 19, 3249-3259. [CrossRef]

84. Pang, Y.; Liu, J.; Li, X.; Zhang, Y.; Zhang, B.; Zhang, J.; Du, N.; Xu, C.; Liang, R.; Ren, H.; et al. Nano Let7b sensitization of eliminating esophageal cancer stemlike cells is dependent on blockade of Wnt activation of symmetric division. Int. J. Oncol. 2017, 51, 1077-1088. [CrossRef]

85. Jin, B.; Wang, W.; Meng, X.X.; Du, G.; Li, J.; Zhang, S.Z.; Zhou, B.H.; Fu, Z.H. Let-7 inhibits self-renewal of hepatocellular cancer stem-like cells through regulating the epithelial-mesenchymal transition and the Wnt signaling pathway. BMC Cancer 2016, 16, 863. [CrossRef]

86. Xiao, G.; Zhang, B.; Meng, J.; Wang, J.; Xu, C.; Tang, S.C.; Li, X.; Zhang, J.; Liang, R.; Ren, H.; et al. miR-367 stimulates Wnt cascade activation through degrading FBXW7 in NSCLC stem cells. Cell Cycle 2017, 16, 2374-2385. [CrossRef]

87. Stratford, E.W.; Daffinrud, J.; Munthe, E.; Castro, R.; Waaler, J.; Krauss, S.; Myklebost, O. The tankyrase-specific inhibitor JW74 affects cell cycle progression and induces apoptosis and differentiation in osteosarcoma cell lines. Cancer Med. 2014, 3, 36-46. [CrossRef] [PubMed]

88. Patterson, M.; Gaeta, X.; Loo, K.; Edwards, M.; Smale, S.; Cinkornpumin, J.; Xie, Y.; Listgarten, J.; Azghadi, S.; Douglass, S.M.; et al. let-7 miRNAs can act through notch to regulate human gliogenesis. Stem Cell Rep. 2014, 3, 758-773. [CrossRef] [PubMed]

89. Bao, B.; Wang, Z.; Ali, S.; Ahmad, A.; Azmi, A.S.; Sarkar, S.H.; Banerjee, S.; Kong, D.; Li, Y.; Thakur, S.; et al. Metformin inhibits cell proliferation, migration and invasion by attenuating CSC function mediated by deregulating miRNAs in pancreatic cancer cells. Cancer Prev. Res. 2012, 5, 355-364. [CrossRef] [PubMed]

90. Bao, B.; Wang, Z.; Ali, S.; Kong, D.; Li, Y.; Ahmad, A.; Banerjee, S.; Azmi, A.S.; Miele, L.; Sarkar, F.H. Notch-1 induces epithelialmesenchymal transition consistent with cancer stem cell phenotype in pancreatic cancer cells. Cancer Lett. 2011, 307, 26-36. [CrossRef] [PubMed]

91. Xiao, G.; Li, X.; Li, G.; Zhang, B.; Xu, C.; Qin, S.; Du, N.; Wang, J.; Tang, S.C.; Zhang, J.; et al. MiR-129 blocks estrogen induction of NOTCH signaling activity in breast cancer stem-like cells. Oncotarget 2017, 8, 103261-103273. [CrossRef]

92. Luo, G.; Long, J.; Cui, X.; Xiao, Z.; Liu, Z.; Shi, S.; Liu, L.; Liu, C.; Xu, J.; Li, M.; et al. Highly lymphatic metastatic pancreatic cancer cells possess stem cell-like properties. Int. J. Oncol. 2013, 42, 979-984. [CrossRef]

93. Ahmad, A.; Maitah, M.Y.; Ginnebaugh, K.R.; Li, Y.; Bao, B.; Gadgeel, S.M.; Sarkar, F.H. Inhibition of Hedgehog signaling sensitizes NSCLC cells to standard therapies through modulation of EMT-regulating miRNAs. J. Hematol. Oncol. 2013, 6, 77. [CrossRef]

94. Alam, M.; Ahmad, R.; Rajabi, H.; Kufe, D. MUC1-C Induces the LIN28B->LET-7->HMGA2 Axis to Regulate Self-Renewal in NSCLC. Mol. Cancer Res. 2015, 13, 449-460. [CrossRef]

95. Guo, L.; Chen, C.; Shi, M.; Wang, F.; Chen, X.; Diao, D.; Hu, M.; Yu, M.; Qian, L.; Guo, N. Stat3-coordinated Lin-28-let-7-HMGA2 and miR-200-ZEB1 circuits initiate and maintain oncostatin M-driven epithelial-mesenchymal transition. Oncogene 2013, 32, 5272-5282. [CrossRef] [PubMed]

96. Guo, L.; Cheng, X.; Chen, H.; Chen, C.; Xie, S.; Zhao, M.; Liu, D.; Deng, Q.; Liu, Y.; Wang, X.; et al. Induction of breast cancer stem cells by M1 macrophages through Lin-28B-let-7-HMGA2 axis. Cancer Lett. 2019, 452, 213-225. [CrossRef] [PubMed]

97. Jiang, R.; Li, Y.; Zhang, A.; Wang, B.; Xu, Y.; Xu, W.; Zhao, Y.; Luo, F.; Liu, Q. The acquisition of cancer stem cell-like properties and neoplastic transformation of human keratinocytes induced by arsenite involves epigenetic silencing of let-7c via Ras/NF-kappaB. Toxicol. Lett. 2014, 227, 91-98. [CrossRef] [PubMed] 
98. Peng, C.Y.; Wang, T.Y.; Lee, S.S.; Hsieh, P.L.; Liao, Y.W.; Tsai, L.L.; Fang, C.Y.; Yu, C.C.; Hsieh, C.S. Let-7c restores radiosensitivity and chemosensitivity and impairs stemness in oral cancer cells through inhibiting interleukin-8. J. Oral Pathol. Med. 2018, 47, 590-597. [CrossRef] [PubMed]

99. Kim, S.J.; Shin, J.Y.; Lee, K.D.; Bae, Y.K.; Sung, K.W.; Nam, S.J.; Chun, K.H. MicroRNA let-7a suppresses breast cancer cell migration and invasion through downregulation of C-C chemokine receptor type 7. Breast Cancer Res. 2012, 14, R14. [CrossRef]

100. Iliopoulos, D.; Hirsch, H.A.; Struhl, K. An epigenetic switch involving NF-kappaB, Lin28, Let-7 MicroRNA, and IL6 links inflammation to cell transformation. Cell 2009, 139, 693-706. [CrossRef] [PubMed]

101. Mao, X.G.; Hutt-Cabezas, M.; Orr, B.A.; Weingart, M.; Taylor, I.; Rajan, A.K.; Odia, Y.; Kahlert, U.; Maciaczyk, J.; Nikkhah, G.; et al. LIN28A facilitates the transformation of human neural stem cells and promotes glioblastoma tumorigenesis through a pro-invasive genetic program. Oncotarget 2013, 4, 1050-1064. [CrossRef]

102. Liu, Y.; Wang, D.; Zhou, M.; Chen, H.; Wang, H.; Min, J.; Chen, J.; Wu, S.; Ni, X.; Zhang, Y.; et al. The KRAS/Lin28B axis maintains stemness of pancreatic cancer cells via the let-7i/TET3 pathway. Mol. Oncol. 2021, 15, 262-278. [CrossRef]

103. Appari, M.; Babu, K.R.; Kaczorowski, A.; Gross, W.; Herr, I. Sulforaphane, quercetin and catechins complement each other in elimination of advanced pancreatic cancer by miR-let-7 induction and K-ras inhibition. Int. J. Oncol. 2014, 45, 1391-1400. [CrossRef] [PubMed]

104. Watanabe, S.; Ueda, Y.; Akaboshi, S.; Hino, Y.; Sekita, Y.; Nakao, M. HMGA2 maintains oncogenic RAS-induced epithelialmesenchymal transition in human pancreatic cancer cells. Am. J. Pathol. 2009, 174, 854-868. [CrossRef] [PubMed]

105. Meder, L.; Konig, K.; Dietlein, F.; Macheleidt, I.; Florin, A.; Ercanoglu, M.S.; Rommerscheidt-Fuss, U.; Koker, M.; Schon, G.; Odenthal, M.; et al. LIN28B enhanced tumorigenesis in an autochthonous KRAS(G12V)-driven lung carcinoma mouse model. Oncogene 2018, 37, 2746-2756. [CrossRef] [PubMed]

106. Ma, X.; Li, C.; Sun, L.; Huang, D.; Li, T.; He, X.; Wu, G.; Yang, Z.; Zhong, X.; Song, L.; et al. Lin28/let-7 axis regulates aerobic glycolysis and cancer progression via PDK1. Nat. Commun. 2014, 5, 5212. [CrossRef] [PubMed]

107. Zhang, Y.; Li, C.; Hu, C.; Wu, Q.; Cai, Y.; Xing, S.; Lu, H.; Wang, L.; Huang, D.; Sun, L.; et al. Lin28 enhances de novo fatty acid synthesis to promote cancer progression via SREBP-1. EMBO Rep. 2019, 20, e48115. [CrossRef]

108. Paz, E.A.; LaFleur, B.; Gerner, E.W. Polyamines are oncometabolites that regulate the LIN28/let-7 pathway in colorectal cancer cells. Mol. Carcinog 2014, 53 (Suppl. 1), E96-E106. [CrossRef]

109. Lozier, A.M.; Rich, M.E.; Grawe, A.P.; Peck, A.S.; Zhao, P.; Chang, A.T.; Bond, J.P.; Sholler, G.S. Targeting ornithine decarboxylase reverses the LIN28/Let-7 axis and inhibits glycolytic metabolism in neuroblastoma. Oncotarget 2015, 6, 196-206. [CrossRef]

110. Gibadulinova, A.; Bullova, P.; Strnad, H.; Pohlodek, K.; Jurkovicova, D.; Takacova, M.; Pastorekova, S.; Svastova, E. CAIXMediated Control of LIN28/let-7 Axis Contributes to Metabolic Adaptation of Breast Cancer Cells to Hypoxia. Int. J. Mol. Sci. 2020, 21, 4299. [CrossRef]

111. Zhu, H.; Shah, S.; Shyh-Chang, N.; Shinoda, G.; Einhorn, W.S.; Viswanathan, S.R.; Takeuchi, A.; Grasemann, C.; Rinn, J.L.; Lopez, M.F.; et al. Lin28a transgenic mice manifest size and puberty phenotypes identified in human genetic association studies. Nat. Genet. 2010, 42, 626-630. [CrossRef]

112. Zhu, H.; Shyh-Chang, N.; Segre, A.V.; Shinoda, G.; Shah, S.P.; Einhorn, W.S.; Takeuchi, A.; Engreitz, J.M.; Hagan, J.P.; Kharas, M.G.; et al. The Lin28/let-7 axis regulates glucose metabolism. Cell 2011, 147, 81-94. [CrossRef]

113. Yu, J.; Vodyanik, M.A.; Smuga-Otto, K.; Antosiewicz-Bourget, J.; Frane, J.L.; Tian, S.; Nie, J.; Jonsdottir, G.A.; Ruotti, V.; Stewart, R.; et al. Induced pluripotent stem cell lines derived from human somatic cells. Science 2007, 318, 1917-1920. [CrossRef]

114. Huang, K.; Maruyama, T.; Fan, G. The naive state of human pluripotent stem cells: A synthesis of stem cell and preimplantation embryo transcriptome analyses. Cell Stem Cell 2014, 15, 410-415. [CrossRef]

115. Takashima, Y.; Guo, G.; Loos, R.; Nichols, J.; Ficz, G.; Krueger, F.; Oxley, D.; Santos, F.; Clarke, J.; Mansfield, W.; et al. Resetting transcription factor control circuitry toward ground-state pluripotency in human. Cell 2014, 158, 1254-1269. [CrossRef]

116. Zhang, J.; Ratanasirintrawoot, S.; Chandrasekaran, S.; Wu, Z.; Ficarro, S.B.; Yu, C.; Ross, C.A.; Cacchiarelli, D.; Xia, Q.; Seligson, M.; et al. LIN28 Regulates Stem Cell Metabolism and Conversion to Primed Pluripotency. Cell Stem Cell 2016, 19, 66-80. [CrossRef]

117. Peng, F.; Wang, J.H.; Fan, W.J.; Meng, Y.T.; Li, M.M.; Li, T.T.; Cui, B.; Wang, H.F.; Zhao, Y.; An, F.; et al. Glycolysis gatekeeper PDK1 reprograms breast cancer stem cells under hypoxia. Oncogene 2018, 37, 1062-1074. [CrossRef]

118. Currie, E.; Schulze, A.; Zechner, R.; Walther, T.C.; Farese, R.V., Jr. Cellular fatty acid metabolism and cancer. Cell Metab. 2013, 18, 153-161. [CrossRef] [PubMed]

119. Zhou, J.; Bi, C.; Ching, Y.Q.; Chooi, J.Y.; Lu, X.; Quah, J.Y.; Toh, S.H.; Chan, Z.L.; Tan, T.Z.; Chong, P.S.; et al. Inhibition of LIN28B impairs leukemia cell growth and metabolism in acute myeloid leukemia. J. Hematol. Oncol. 2017, 10, 138. [CrossRef] [PubMed]

120. Chen, K.J.; Hou, Y.; Wang, K.; Li, J.; Xia, Y.; Yang, X.Y.; Lv, G.; Xing, X.L.; Shen, F. Reexpression of Let-7g microRNA inhibits the proliferation and migration via K-Ras/HMGA2/snail axis in hepatocellular carcinoma. Biomed. Res. Int. 2014, $2014,742417$. [CrossRef] [PubMed]

121. Wang, H.; Ren, Y.; Qian, C.; Liu, J.; Li, G.; Li, Z. Over-expression of CDX2 alleviates breast cancer by up-regulating microRNA let-7b and inhibiting COL11A1 expression. Cancer Cell Int. 2020, 20, 13. [CrossRef]

122. Esquela-Kerscher, A.; Trang, P.; Wiggins, J.F.; Patrawala, L.; Cheng, A.; Ford, L.; Weidhaas, J.B.; Brown, D.; Bader, A.G.; Slack, F.J. The let-7 microRNA reduces tumor growth in mouse models of lung cancer. Cell Cycle 2008, 7, 759-764. [CrossRef] [PubMed] 
123. Kumar, M.S.; Erkeland, S.J.; Pester, R.E.; Chen, C.Y.; Ebert, M.S.; Sharp, P.A.; Jacks, T. Suppression of non-small cell lung tumor development by the let-7 microRNA family. Proc. Natl. Acad. Sci. USA 2008, 105, 3903-3908. [CrossRef] [PubMed]

124. Nadiminty, N.; Tummala, R.; Lou, W.; Zhu, Y.; Shi, X.B.; Zou, J.X.; Chen, H.; Zhang, J.; Chen, X.; Luo, J.; et al. MicroRNA let-7c is downregulated in prostate cancer and suppresses prostate cancer growth. PLoS ONE 2012, 7, e32832. [CrossRef] [PubMed]

125. Li, Y.; VandenBoom, T.G., 2nd; Kong, D.; Wang, Z.; Ali, S.; Philip, P.A.; Sarkar, F.H. Up-regulation of miR-200 and let-7 by natural agents leads to the reversal of epithelial-to-mesenchymal transition in gemcitabine-resistant pancreatic cancer cells. Cancer Res. 2009, 69, 6704-6712. [CrossRef] [PubMed]

126. Huang, T.H.; Wu, A.T.H.; Cheng, T.S.; Lin, K.T.; Lai, C.J.; Hsieh, H.W.; Chang, P.M.; Wu, C.W.; Huang, C.F.; Chen, K.Y. In silico identification of thiostrepton as an inhibitor of cancer stem cell growth and an enhancer for chemotherapy in non-small-cell lung cancer. J. Cell. Mol. Med. 2019, 23, 8184-8195. [CrossRef] [PubMed]

127. Thanasupawat, T.; Natarajan, S.; Rommel, A.; Glogowska, A.; Bergen, H.; Krcek, J.; Pitz, M.; Beiko, J.; Krawitz, S.; Verma, I.M.; et al. Dovitinib enhances temozolomide efficacy in glioblastoma cells. Mol. Oncol. 2017, 11, 1078-1098. [CrossRef]

128. Park, S.J.; Heo, K.; Choi, C.; Yang, K.; Adachi, A.; Okada, H.; Yoshida, Y.; Ohno, T.; Nakano, T.; Takahashi, A. Carbon ion irradiation abrogates Lin28B-induced X-ray resistance in melanoma cells. J. Radiat. Res. 2017, 58, 765-771. [CrossRef]

129. Yu, D.; Liu, X.; Han, G.; Liu, Y.; Zhao, X.; Wang, D.; Bian, X.; Gu, T.; Wen, L. The let-7 family of microRNAs suppresses immune evasion in head and neck squamous cell carcinoma by promoting PD-L1 degradation. Cell Commun. Signal. 2019, 17, 173. [CrossRef]

130. Minciacchi, V.R.; Freeman, M.R.; Di Vizio, D. Extracellular vesicles in cancer: Exosomes, microvesicles and the emerging role of large oncosomes. Semin. Cell Dev. Biol. 2015, 40, 41-51. [CrossRef]

131. Yuana, Y.; Sturk, A.; Nieuwland, R. Extracellular vesicles in physiological and pathological conditions. Blood Rev. 2013, 27, 31-39. [CrossRef] [PubMed]

132. Xu, S.; Zheng, L.; Kang, L.; Xu, H.; Gao, L. microRNA-let-7e in serum-derived exosomes inhibits the metastasis of non-small-cell lung cancer in a SUV39H2/LSD1/CDH1-dependent manner. Cancer Gene Ther. 2021, 28, 250-264. [CrossRef] [PubMed]

133. Zhang, Y.F.; Zhou, Y.Z.; Zhang, B.; Huang, S.F.; Li, P.P.; He, X.M.; Cao, G.D.; Kang, M.X.; Dong, X.; Wu, Y.L. Pancreatic cancerderived exosomes promoted pancreatic stellate cells recruitment by pancreatic cancer. J. Cancer 2019, 10, 4397-4407. [CrossRef] [PubMed]

134. Hannafon, B.N.; Carpenter, K.J.; Berry, W.L.; Janknecht, R.; Dooley, W.C.; Ding, W.Q. Exosome-mediated microRNA signaling from breast cancer cells is altered by the anti-angiogenesis agent docosahexaenoic acid (DHA). Mol. Cancer 2015, 14, 133. [CrossRef] [PubMed]

135. Ohshima, K.; Inoue, K.; Fujiwara, A.; Hatakeyama, K.; Kanto, K.; Watanabe, Y.; Muramatsu, K.; Fukuda, Y.; Ogura, S.; Yamaguchi, K.; et al. Let-7 microRNA family is selectively secreted into the extracellular environment via exosomes in a metastatic gastric cancer cell line. PLoS ONE 2010, 5, e13247. [CrossRef]

136. Li, Y.; Zhang, X.; Chen, D.; Ma, C. Let-7a suppresses glioma cell proliferation and invasion through TGF-beta/Smad3 signaling pathway by targeting HMGA2. Tumour Biol. 2016, 37, 8107-8119. [CrossRef]

137. Trang, P.; Medina, P.P.; Wiggins, J.F.; Ruffino, L.; Kelnar, K.; Omotola, M.; Homer, R.; Brown, D.; Bader, A.G.; Weidhaas, J.B.; et al. Regression of murine lung tumors by the let-7 microRNA. Oncogene 2010, 29, 1580-1587. [CrossRef] [PubMed]

138. Han, X.; Zhang, J.J.; Han, Z.Q.; Zhang, H.B.; Wang, Z.A. Let-7b attenuates cisplatin resistance and tumor growth in gastric cancer by targeting AURKB. Cancer Gene Ther. 2018, 25, 300-308. [CrossRef]

139. Li, H.; Fang, Z.; Yuan, B.; Ma, S.-L.; Li, A.-J.; Zhou, W.-P.; Zhang, Y.-J.; Yin, L. MicroRNA let-7b inhibits cell proliferation via upregulation of p21 in hepatocellular carcinoma. Cell Biosci. 2020, 10, 83. [CrossRef]

140. Cai, J.; Yang, C.; Yang, Q.; Ding, H.; Jia, J.; Guo, J.; Wang, J.; Wang, Z. Deregulation of let-7e in epithelial ovarian cancer promotes the development of resistance to cisplatin. Oncogenesis 2013, 2, e75. [CrossRef]

141. Hu, H.; Zhao, X.; Jin, Z.; Hou, M. Hsa-let-7g miRNA regulates the anti-tumor effects of gastric cancer cells under oxidative stress through the expression of DDR genes. J. Toxicol. Sci. 2015, 40, 329-338. [CrossRef]

142. Zhou, J.L.; Deng, S.; Fang, H.S.; Yu, G.; Peng, H. Hsa-let-7g promotes osteosarcoma by reducing HOXB1 to activate NF-kB pathway. Biomed. Pharmacother. 2019, 109, 2335-2341. [CrossRef] [PubMed]

143. Hosseinahli, N.; Aghapour, M.; Duijf, P.H.G.; Baradaran, B. Treating cancer with microRNA replacement therapy: A literature review. J. Cell Physiol. 2018, 233, 5574-5588. [CrossRef]

144. Chen, Y.; Gao, D.Y.; Huang, L. In vivo delivery of miRNAs for cancer therapy: Challenges and strategies. Adv. Drug Deliv. Rev. 2015, 81, 128-141. [CrossRef]

145. Chirshev, E.; Oberg, K.C.; Ioffe, Y.J.; Unternaehrer, J.J. Let-7 as biomarker, prognostic indicator, and therapy for precision medicine in cancer. Clin. Transl. Med. 2019, 8, 24. [CrossRef]

146. Trang, P.; Wiggins, J.F.; Daige, C.L.; Cho, C.; Omotola, M.; Brown, D.; Weidhaas, J.B.; Bader, A.G.; Slack, F.J. Systemic delivery of tumor suppressor microRNA mimics using a neutral lipid emulsion inhibits lung tumors in mice. Mol. Ther. 2011, 19, 1116-1122. [CrossRef]

147. Zhou, K.; Nguyen, L.H.; Miller, J.B.; Yan, Y.; Kos, P.; Xiong, H.; Li, L.; Hao, J.; Minnig, J.T.; Zhu, H.; et al. Modular degradable dendrimers enable small RNAs to extend survival in an aggressive liver cancer model. Proc. Natl. Acad. Sci. USA 2016, 113, 520-525. [CrossRef] 
148. Dai, X.; Fan, W.; Wang, Y.; Huang, L.; Jiang, Y.; Shi, L.; McKinley, D.; Tan, W.; Tan, C. Combined Delivery of Let-7b MicroRNA and Paclitaxel via Biodegradable Nanoassemblies for the Treatment of KRAS Mutant Cancer. Mol. Pharm. 2016, 13, 520-533. [CrossRef]

149. Esposito, C.L.; Cerchia, L.; Catuogno, S.; De Vita, G.; Dassie, J.P.; Santamaria, G.; Swiderski, P.; Condorelli, G.; Giangrande, P.H.; de Franciscis, V. Multifunctional aptamer-miRNA conjugates for targeted cancer therapy. Mol. Ther. 2014, 22, 1151-1163. [CrossRef] [PubMed]

150. Rupaimoole, R.; Slack, F.J. MicroRNA therapeutics: Towards a new era for the management of cancer and other diseases. Nat. Rev. Drug Discov. 2017, 16, 203-222. [CrossRef] [PubMed]

151. Bader, A.G. miR-34-A microRNA replacement therapy is headed to the clinic. Front. Genet. 2012, 3, 120. [CrossRef] [PubMed]

152. Wells, A.C.; Daniels, K.A.; Angelou, C.C.; Fagerberg, E.; Burnside, A.S.; Markstein, M.; Alfandari, D.; Welsh, R.M.; Pobezinskaya, E.L.; Pobezinsky, L.A. Modulation of let-7 miRNAs controls the differentiation of effector CD8 T cells. Elife 2017, 6. [CrossRef] [PubMed]

153. Gilles, M.E.; Slack, F.J. Let-7 microRNA as a potential therapeutic target with implications for immunotherapy. Expert Opin. Ther. Targets 2018, 22, 929-939. [CrossRef] [PubMed] 